\title{
Pilot in situ auger mixing treatment of a contaminated site. Part 4. Performance at five years
}

\section{A. Al-Tabbaa and N. Boes}

Parts I, 2 and 3 of this series of publications gave details of the development and application of a pilot in situ auger mixing treatment on a contaminated site in West Drayton, Middlesex. The treatment method employed was in situ stabilisation/solidification using cement-based grouts and applied using a soil-mixing auger. In these publications, details were given of the initial laboratory treatability study, the site trial and subsequent laboratory assessment of the treated contaminated made ground using samples cored at 55 days and tested at $0.2,1 \cdot 2$ and 2.4 years after treatment. Recently, further coring of the treated ground took place at $\mathbf{4 . 5}$ years of in situ curing and the samples were tested at around 5 years after treatment. Hence this paper presents the longer-term behaviour of the in situ cured stabilised/solidified contaminated ground in terms of physical and chemical properties such as strength, leachability, leachate $\mathrm{pH}$, permeability, freeze-thaw and wet-dry durability and microstructural analyses. The performance is presented of both soil types present, made ground and sand and gravel, from both single and overlap column mixes. The paper provides an insight into the effectiveness of the treatment at 5 years, a correlation between the performance of the different soils and mix conditions, and an assessment of the applicability of the available test methods and test criteria imposed.

\section{INTRODUCTION}

Validation of the long-term effectiveness of any contaminated land remediation methodology is essential for its success. Although in situ stabilisation/solidification of contaminated ground has become a well-established remediation methodology in the USA, data on the long-term effectiveness are still scarce. Such data are even more scarce in the UK, where the technology has only recently emerged, with recent publications emphasising the need for such data. ${ }^{1}$ A literature review of the available published results of the behaviour of cement-treated contaminated soils was presented in Part 3 of this series of publications. ${ }^{2}$ Since then a small number of further studies have been published. This includes the results of work on a 3.3 year old heavy metal and organic contaminated soil treated ex situ with a cement-based grout that contained a proprietary agent. ${ }^{3,4}$ This is a continuation of work in which the results at up to $1 \cdot 25$ years were presented. ${ }^{5}$ In these publications, no information was provided on the grout details or the proprietary additive content. The treated soil was laid out in the form of slabs and left exposed above ground before testing. Acceptable strength values, which increased linearly on a log time scale, and permeability values were obtained. This work also concluded that although some metals and some hydrocarbons were effectively immobilised, others such as lead, chromium and total polycyclic aromatic hydrocarbons were not. $^{3}$

\section{WEST DRAYTON RESEARCH AND DEVELOPMENT PROJECT}

The West Drayton project, initiated in 1994, involved the development and implementation of an in situ soil-mixed stabilisation/solidification pilot treatment on a contaminated site in West Drayton. Initial treatability study work ${ }^{6}$ using site soils arrived at seven different cement-based grout mixes, which were applied during a site trial in April 1995. ${ }^{7}$ Coring of the top $1.2 \mathrm{~m}$ of the treated made ground from single columns took place only 55 days after treatment. The cores were tested for various physical and chemical properties at $0 \cdot 2$ years after treatment. The remaining samples were then cured under laboratory conditions and tested at $1 \cdot 2$ and $2 \cdot 4$ years after treatment. ${ }^{2}$ The properties tested included unconfined compressive strength, leachability, leachate $\mathrm{pH}$, freeze-thaw and wet-dry durability, permeability and microstructural analyses. In October 1999 the treated site area was cored again after 4.5 years of in situ curing. Extensive coring of the whole treated area took place, and an extensive programme of testing was performed on the retrieved samples. This paper presents the results of this investigation. This study is the first of its kind in the UK. The aim is to investigate the 5-year behaviour of different zones of this aged treated ground and the timerelated development of the investigated properties, and to assess the effectiveness of the available test methods and imposed design criteria.

\section{SITE AND GROUT MIX DETAILS}

The ground conditions at the site are as detailed in Table 1. They consisted of $1.7 \mathrm{~m}$ of variable made ground, which included extraneous objects such as glass, brick and metal, overlying natural sand and gravel deposits. The groundwater was observed at a depth of $2 \mathrm{~m}$ below ground level. The type 


\begin{tabular}{ll}
\hline Soil description & Depth: $\mathrm{m}$ \\
\hline Made ground: sand & $0 \cdot 10-0.40$ \\
Made ground: clayey sand & $0 \cdot 40-0.87$ \\
Made ground: silty clay & $0 \cdot 87-1.62$ \\
Made ground: spongy peat & $1 \cdot 62-1 \cdot 72$ \\
Sand: fine to coarse with gravel & $1 \cdot 72-2 \cdot 00$ \\
Gravel: fine to coarse with sand & $2 \cdot 00-2 \cdot 30$ \\
& \\
Table I. Description of the site soils encountered
\end{tabular}

and concentration of contaminants in both soil types and in the groundwater are detailed in Table $2{ }^{8}$ which shows high levels of a number of heavy metals and organic compounds (that is, above the threshold trigger levels for soils specified by the Interdepartmental Committee for the Redevelopment of Contaminated Land ${ }^{9}$ and above the Dutch Intervention Values for soil and groundwater ${ }^{10}$ ). The concentration of some of the contaminants in the sand and gravel indicates a decrease with depth.

The layout of the 23 overlapping columns installed during the site trial ${ }^{7}$ is shown in Fig. 1. The solid circles A-G represent the single columns installed on the first day, and the dashed circles Bo-Eo represent the overlapping columns installed on the second day. The letters $A-G$ refer to the seven different soil-grout mixes applied, detailed in Table 3. Mixes A and B contained cement and pulverised fuel ash (PFA), mixes C-F contained lime in addition, and mix G contained cement and bentonite. The range by percentage weight of the various additives in the soil-grout mixes is summarised in the pie chart in Fig. 2. This shows that the cement content applied at $1-6 \%$ is relatively low, which was intentional in order to investigate low-strength soil-grout material.

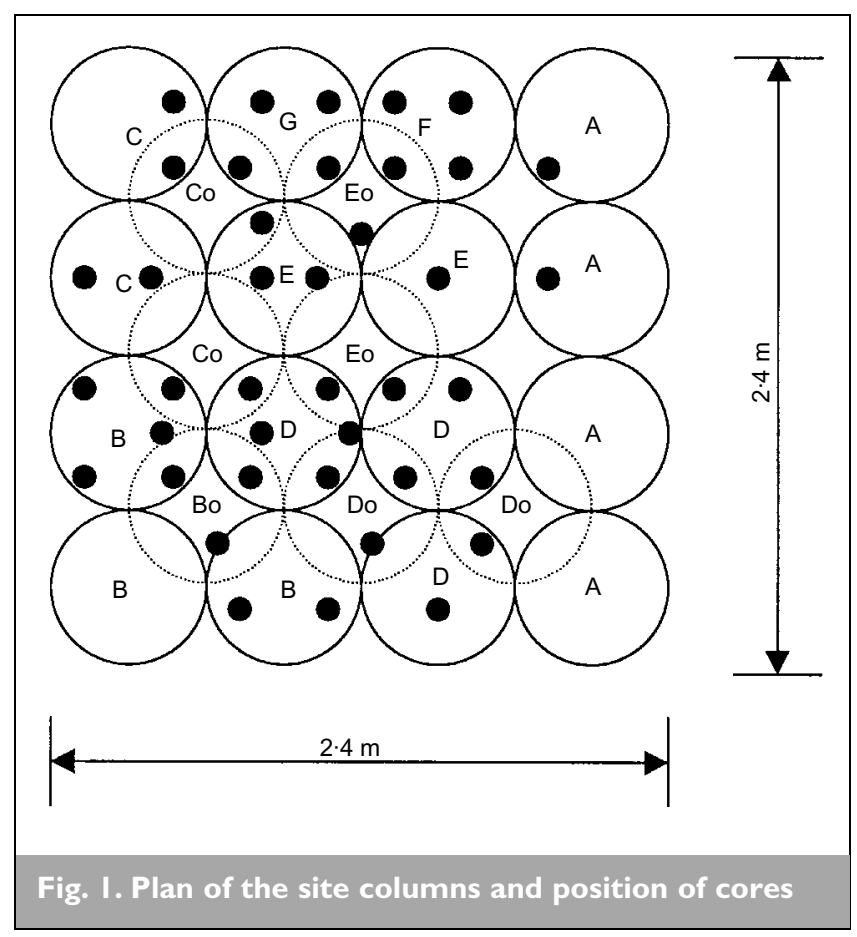

\section{CORING OF THE TREATED GROUND}

During the furst coring at 55 days after treatment most of the treated area was excavated down to a depth of $1.2 \mathrm{~m}$. Hence this time the ground was excavated down to a depth of $1.3 \mathrm{~m}$, at which level coring was started. The intention was to retrieve cores of up to $1 \mathrm{~m}$ depth-that is, to the full depth of the treatment-and hence to obtain cores from both the made ground and the sand and gravel zones. As the treated area was bound by underground services on three sides it was only possible to expose one side to locate the boundary of the columns, which was sufficient to map out the column

\begin{tabular}{|c|c|c|c|c|}
\hline \multirow[t]{2}{*}{ Contaminant } & \multicolumn{3}{|c|}{ Sample (depth) } & \multirow{2}{*}{$\begin{array}{c}\text { Water }(2.25 \mathrm{~m}) \\
\mathrm{pH} 7 \cdot 3\end{array}$} \\
\hline & $\begin{array}{l}\text { Made ground } \\
(0.7 \mathrm{~m}) ; \mathrm{pH} 8.2\end{array}$ & $\begin{array}{l}\text { Sand and gravel } \\
(2 \cdot 1 \mathrm{~m}) ; \mathrm{pH} 7 \cdot 2\end{array}$ & $\begin{array}{l}\text { Sand and gravel } \\
(2.6 \mathrm{~m}) ; \mathrm{pH} 7.8\end{array}$ & \\
\hline Arsenic & $13 \cdot 8$ & $30 \cdot 0$ & $2 \cdot 4$ & 0.48 \\
\hline Cadmium & $8 \cdot 7$ & $8 \cdot 7$ & $2 \cdot 3$ & 0.59 \\
\hline Lead & 2801 & 2345 & 2785 & 438 \\
\hline Copper & 1264 & 962 & 626 & $52 \cdot 8$ \\
\hline Nickel & 105 & 232 & 24 & 10.5 \\
\hline Zinc & 1589 & 1800 & 295 & $94 \cdot 8$ \\
\hline Mercury & $15 \cdot 5$ & $3 \cdot 7$ & $1 \cdot 8$ & 0.46 \\
\hline Total Chromium & 302 & 31 & 60 & 0.55 \\
\hline Barium & 338 & 163 & 119 & $22 \cdot 03$ \\
\hline Total Cyanide & $1 \cdot 2$ & $4 \cdot 5$ & $<0.1$ & 0.05 \\
\hline Total Boron & 128 & 176 & 68 & \\
\hline Total Sulphate & 1000 & 2000 & 2000 & 297 \\
\hline Toluene extract & 1700 & 8700 & 600 & \\
\hline Coal tar & 1400 & 6200 & 200 & $<1$ \\
\hline Phenols & $<1$ & $<1$ & $<1$ & $<0.1$ \\
\hline Mineral oil & 566 & 1900 & 325 & 30 \\
\hline Paraffin hydrocarbons & 165 & 142 & 85 & \\
\hline
\end{tabular}

positions. Cores, $100 \mathrm{~mm}$ in diameter, were obtained from all the single and overlap column zones. A layout of the cores obtained in relation to the columns is

superimposed on Fig. 1; the positions of the cores were accurate to within $\pm 10 \mathrm{~cm}$.

Initial coring using water proved to be very difficult, resulting in badly fragmented cores, and hence a polymer was used. The retrieved cores were washed to remove traces of the polymer, and subsequent microstructural investigation showed that it had not penetrated into the samples. The coring was problematic because of the presence of metal wire segments, which caused three carbon black cutter heads to completely wear out. The 


\begin{tabular}{|c|c|c|c|c|}
\hline Mix & Cement: PFA: lime: bentonite & Water: dry grout & Soil : grout & Soil : dry grout \\
\hline$A$ & $2: 8: 0: 0$ & $0.42: 1$ & $5: 1$ & $7: 1$ \\
\hline B & $3: 8: 0: 0$ & $0.42: 1$ & $5: 1$ & $7: 1$ \\
\hline C & $2 \cdot 5: 8: 0 \cdot 4: 0$ & $0.42: 1$ & $5: 1$ & $7: 1$ \\
\hline D & $3: 8: 0 \cdot 1: 0$ & $0.42: 1$ & $5: 1$ & $7: 1$ \\
\hline $\mathrm{E}$ & $2 \cdot 5: 8: 0 \cdot 4: 0$ & $0.42: 1$ & $3 \cdot 5: 1$ & $5: 1$ \\
\hline $\mathrm{F}$ & $2 \cdot 5: 8: 0 \cdot 4: 0$ & $0 \cdot 30: 1$ & $3 \cdot 9: 1$ & $5: 1$ \\
\hline G & $8: 0: 0: 0 \cdot 8$ & $1 \cdot 6: 1$ & $3 \cdot 7: 1$ & $9 \cdot 7: 1$ \\
\hline
\end{tabular}

(c) During the column installation process the auger might sometimes have been driven from verticality by the presence of obstructions. Typical contaminated made ground does usually contain a large amount of extraneous objects. For commercial installations, attention needs to be paid to the presence of such obstructions: perhaps some form of probing

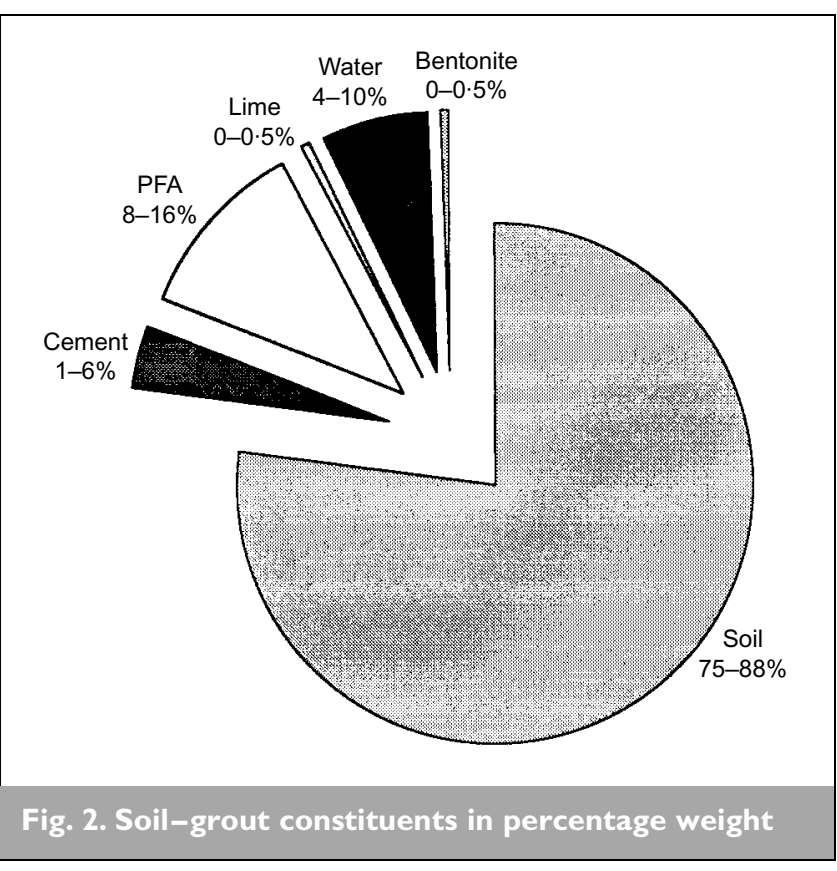

consequence of this was that some of the cores were made up of smaller sections, although a number of intact cores were obtained, and the site work took 7 days rather than the 4 days originally envisaged. The cored area is shown in Fig. 3.

Up to forty $1 \mathrm{~m}$ length cores were attempted, of which a total of $27 \mathrm{~m}$ of cores were obtained. The loss of material could have been caused by a number of reasons.

(a) The full depth of the core might have been shorter than anticipated. This could have been caused by the treatment not having been carried out to the full depth of $2.3 \mathrm{~m}$, or by the top surface being washed away by the jetting action.

(b) During the site trial the position of the columns was located only roughly (to $\pm 10 \mathrm{~cm}$ ), and hence it is possible that gaps might have been left between the single columns. The exact positioning of the columns in this project was not crucial since the extent of the columns was clear from the surface during and soon after the trial, and only a limited number of shallow cores were going to be extruded then. The extensive coring exercise reported here was not planned when the site trial was carried out back in 1995. would need to be performed prior to augering to remove or reduce the size of obstructions.

(d) Some of the injected grout might have been lost into a disused sewer, as was observed during the site trial, when one of the columns had to be regrouted.

(e) When cores broke, it was not possible with the coring equipment used to retrieve sections at the bottom of the core.

The cores were all physically examined, and although most of them were of high quality, it was clear that some cores were of better quality than others, as can be seen in Fig. 4. Generally the cores from the single columns E and G were the most intact and of the highest quality, and those of mix D single and overlap columns were the weakest and most fragmented. This observation was also recorded during the first coring exercise. ${ }^{11}$ This behaviour is not consistent with the cement content in the grout or whether the cores came from a single or overlap column.

Although it is clear from Fig. 1 that some of the cores could have come from the zones where single and overlap columns met, there was no physical sign of any such boundary at these positions in the cores. The cores in Fig. 4 also show that there was effective mixing between the made ground and the sand and gravel at their interface. Hence, for the purpose of testing the two different materials, the material above a depth of $1.7 \mathrm{~m}$-the natural boundary between the two soil strata-was considered to be made ground, and that below to be sand and gravel.

\section{EXPERIMENTAL PROCEDURE}

The cores were trimmed using a diamond saw cutter into different lengths as applicable to the various test methods. A number of physical and chemical properties were investigated, as with the earlier cores, ${ }^{2,7}$ using standard tests carried out on the core samples in which the same preparation and test methods were employed. These were the unconfined compressive strength (UCS), ${ }^{12}$ permeability, ${ }^{13}$ wet-dry and freeze-thaw durability, ${ }^{14,15}$ toxicity characteristic leaching procedure (TCLP) ${ }^{16}$ and National Rivers Authority (NRA) ${ }^{17}$ leachability of both heavy metals and hydrocarbons, leachate $\mathrm{pH}$, and microstructural analyses using scanning electron microscopy (SEM) and x-ray diffraction (XRD) techniques. Details of the design criteria and test procedures used were 


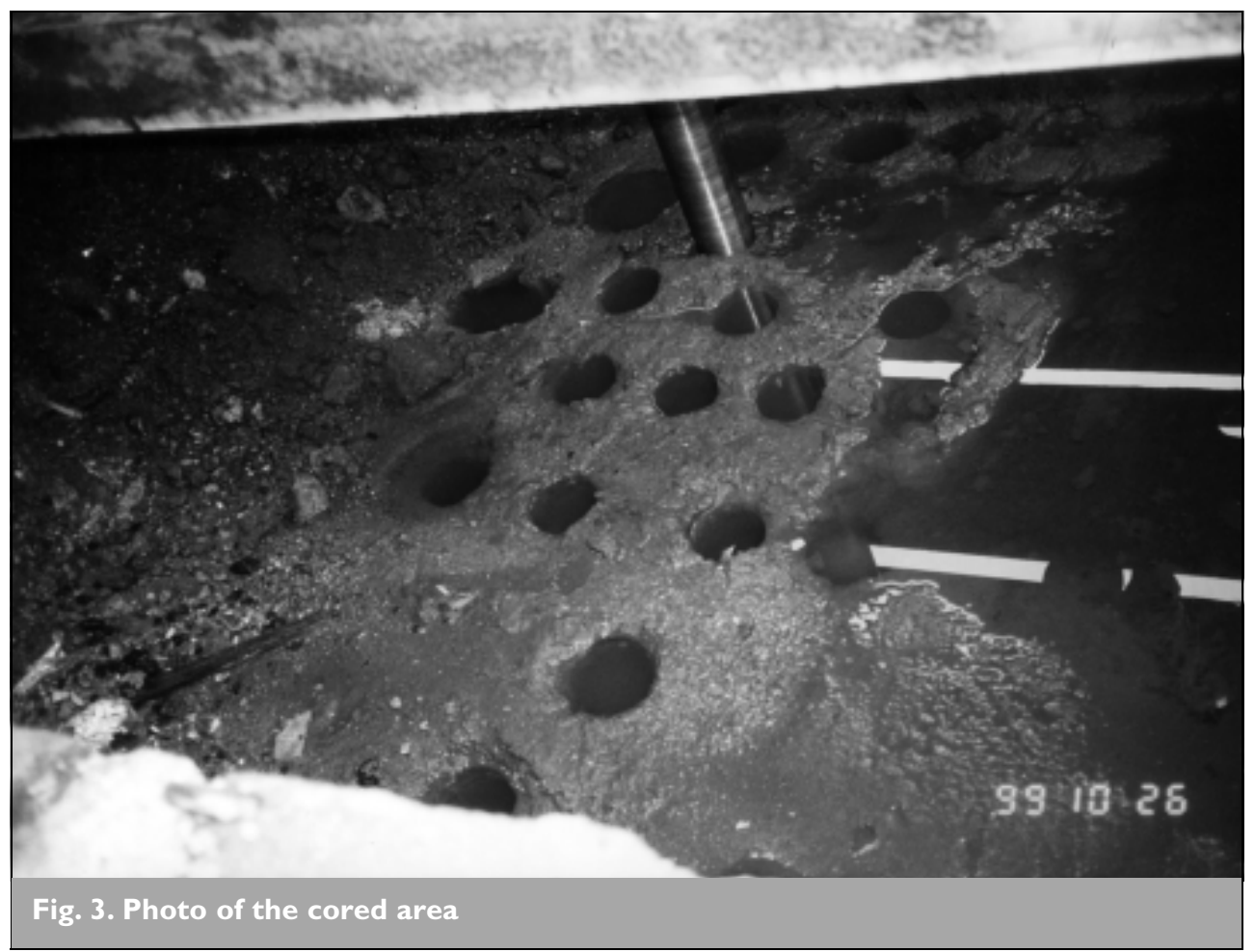

distortion of the results.

Previously used correlations, ${ }^{2,7}$ similar to those used for concrete samples, ${ }^{11,22}$ relating the strength of the samples tested to samples that are $200 \mathrm{~mm}$ high, are used here to facilitate direct comparisons. Up to four samples were tested for each mix, and the complete set of average UCS results at 5 years for each mix is shown in Table 5 , with an average variation of $\pm 26 \%$. Table 5 shows a wide range of UCS values, from $1218 \mathrm{kPa}$ up to $6090 \mathrm{kPa}$. The overall average UCS value of the made ground singlecolumn mixes is $3870 \mathrm{kPa}$. The relative performance of the made ground mixes is consistent with the grout content. For example, mix A is weaker than mix B as it contains less cement, and

given previously, ${ }^{2,6,7}$ and are summarised here in Table 4 . Full details of the experimental procedure are given elsewhere. ${ }^{21}$

\section{RESULTS AND DISCUSSION}

A complete set of results is presented here, which includes not only the results of the made ground from the single columns, which was the only material tested previously, ${ }^{2,7}$ but also the results of the sand and gravel beneath and the overlap columns. The previous results of the made ground singlecolumn mixes at 0.2 and $2 \cdot 4$ years are also presented here for comparison purposes. Each test is discussed separately below. The tested samples were aged between 4.7 and 5.9 years. This is because it was not possible to perform all the tests at the same time. In addition, in some of the tests, such as permeability and durability, it was not possible to test all the samples at the same time. Hence a testing schedule had to be set up, and the testing programme was completed in just over a year. For convenience an average age of 5 years is used throughout. The results are also assessed against the design criteria originally set, as summarised in Table 4.

Different lengths of cores were obtained from the various mixes. Only very limited lengths of core were obtained for mixes $\mathrm{A}$ and Do, and hence the results of those mixes are based on a limited number of tests and are the least reliable. The results presented are the average of between two and four samples being tested for each mix and for each test. The average bulk densities of all the treated made ground and sand and gravel samples were similar at $1970 \mathrm{~kg} / \mathrm{m}^{3} \pm 5 \cdot 6 \%$ and $2000 \mathrm{~kg} / \mathrm{m}^{3} \pm 8 \%$ respectively.

\section{I. Unconfined compressive strength}

Unconfined compressive strength (UCS) ${ }^{12}$ tests were performed on samples $100 \mathrm{~mm}$ in diameter and $100 \mathrm{~mm}$ high, which were selected not to contain large extraneous objects to avoid any mixes $\mathrm{C}, \mathrm{E}$ and $\mathrm{F}$, which contain the same grout, show that mix $\mathrm{C}$ with the lowest grout content has the lowest strength, while mix F with the smallest water content has the highest strength. The UCS values of the sand and gravel single-column mixes were generally in the same range as those of the made ground, with an overall average of $4030 \mathrm{kPa}$. In the sand and gravel mixes there was no particular trend relating the strength values to the grout constituents or content.

The UCS values of the made ground overlap-column mixes were generally much lower than those of the single-column mixes, with an overall average value of $2670 \mathrm{kPa}$. The UCS values of the sand and gravel overlap column mixes were slightly lower than the corresponding single-column mixes, with an average of $3760 \mathrm{kPa}$. As the overlap column mixes are expected to contain up to twice the grout content of the singlemix columns, depending on the strength of the single columns and the installation operation, they would be expected to be stronger. The lower values observed could be a result of the way in which the overlap columns were formed. They were augered, with difficulty, through the one-day-old single columns, and so it is likely that a reduced amount of grout was injected and that effective mixing of the grout and soil was not achieved, resulting in the overlap columns being made up of lumps of single-column mix material coated with grout. Physical inspection of the overlap column samples supports this interpretation, in that they were generally weaker-quality cores than those of the single-column mixes. The observed visual weakness of mix Do is clear from the very low UCS obtained for both the made ground and sand and gravel mixes.

The time-related performance of the made ground singlecolumn mixes is shown in Fig. 5(a). Two of the mixes show a relatively linear increase over the 5-year period, two show some decrease, and the remaining three mixes suggest that the 


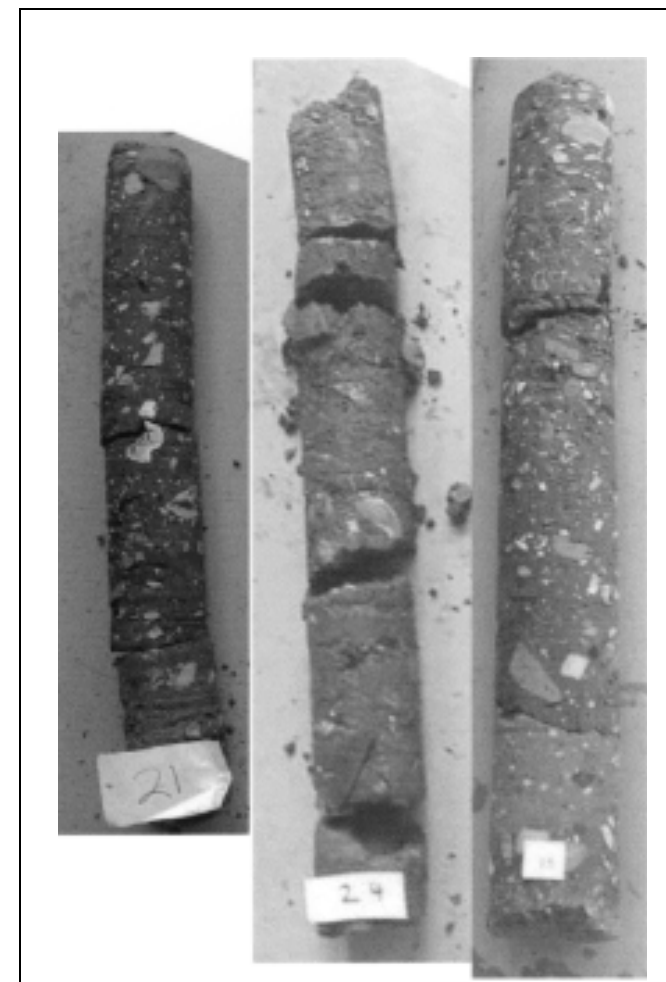

(a)

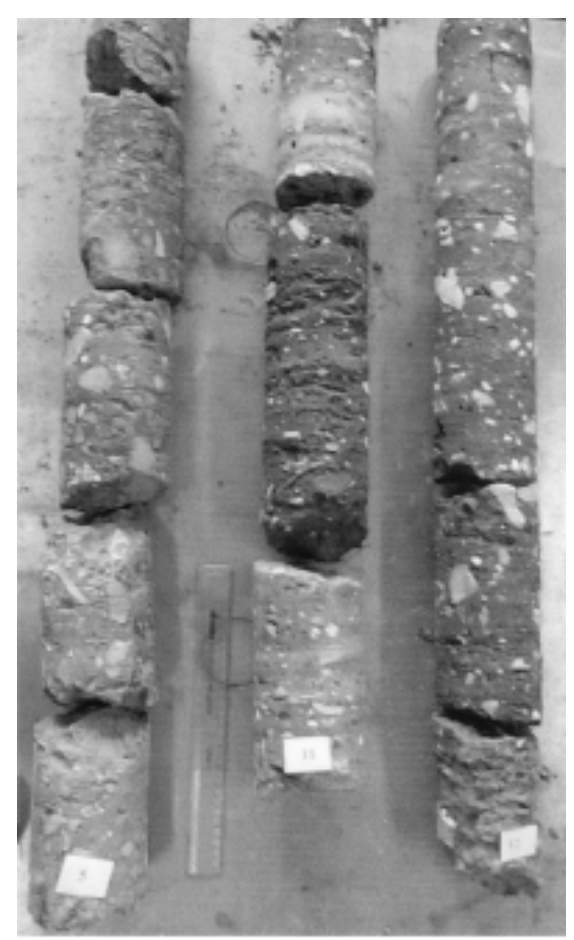

(b)

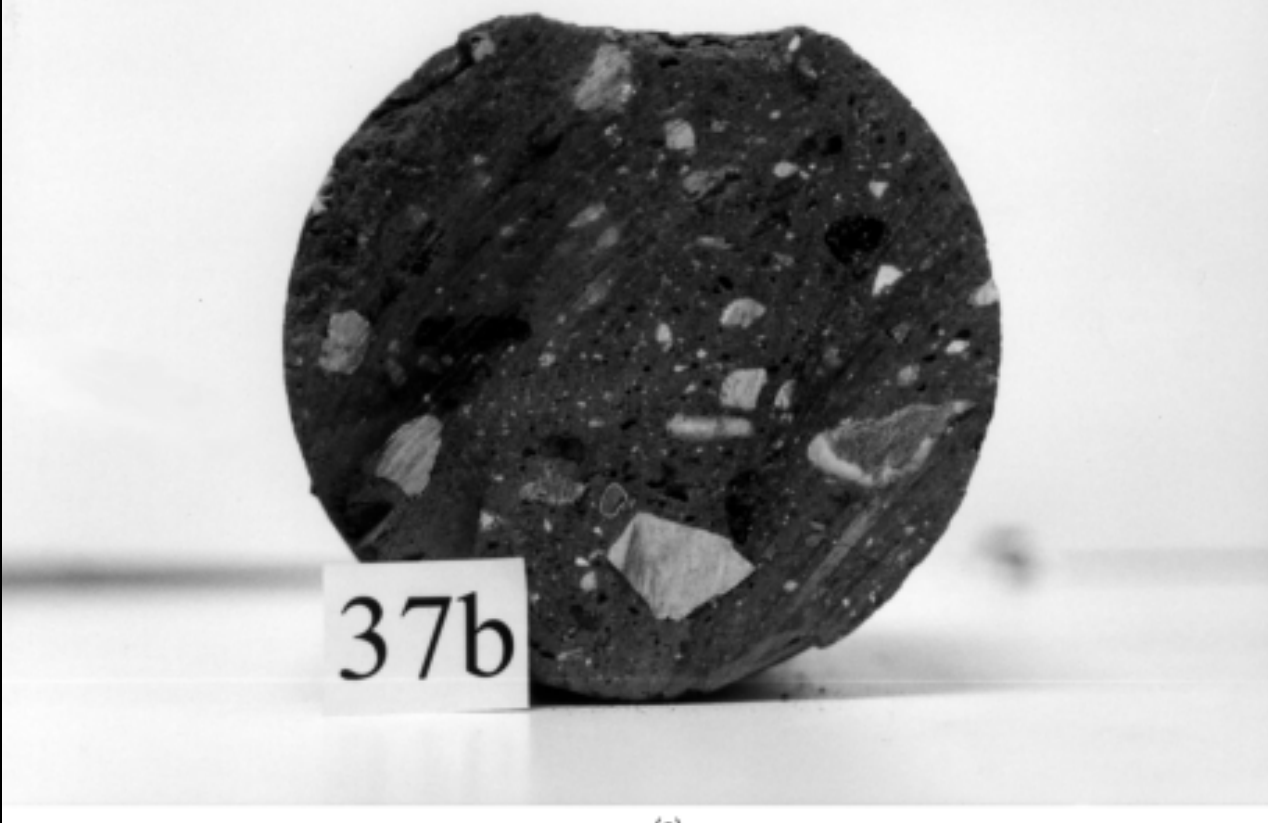

(c)

Fig. 4. Typical examples of the retrieved cores: (a) mix C; (b) mix Co; (c) crosssection of $\mathrm{mix} B o$

strength is reaching a plateau at 5 years. It is clear that the spread of the values obtained seems to increase with time along with the variability in the results. In some mixes, such as mix $B$, the strength almost doubled compared with that at $2 \cdot 4$ years, whereas for mix A the strength reduced by 15\%. This perhaps implies that numerous factors that affect the strength development of such mixes come into play over time, such as interaction with contaminants, and in situ curing conditions. A possible reason for the reduction in UCS of mix A could be the limited amount of cement present in it: at 2.3\%, mix A contains the lowest amount of cement of all the mixes. This limited cement content might mean that the slow long-term hydration had ceased, and additional factors that would cause a reduction in strength have now become dominant. This would imply the possible presence of a threshold for the minimum cement content that would be required for maintaining the long-term development of UCS of the mixes. The smaller reduction in strength of mix G could be caused by the presence of the bentonite and the effect of a long-term increased interaction between the bentonite and the contaminants present. Having said that, it is worth pointing out, as detailed in Part 3 of this series of publications, ${ }^{2}$ that the UCS of mix D decreased by $18 \%$ from $1 \cdot 2$ years to $2 \cdot 4$ years and then doubled at 5 years compared with $2 \cdot 4$ years. Hence it seems that some fluctuations in the UCS of such materials with time are to be expected and perhaps allowed for. In addition, further investigation of the above-mentioned factors in isolation is currently being performed in a follow-on EPSRC project to enable recommendations to be made on how these factors can be allowed for in practice.

The strength at 5 years is between three and six times greater than that at $0 \cdot 2$ years, which is perhaps an indication of the continual in situ long-term hydration of cementitious materials in the presence of contamination. If the UCS results are plotted against the logarithm of time, as shown in Fig. 5(b), then apart from mixes A and G, which showed a reduction in UCS at 5 years, three mixes showed a linear increase and two mixes showed a deviation from linearity in a concave manner. The linear increase is consistent with the behaviour observed by others on similar mixes, ${ }^{3}$ and the concave behaviour (mixes B and D) is consistent with that of cement-treated uncontaminated soils that contain pozzolanic materials. ${ }^{23}$ 


\begin{tabular}{|c|c|c|c|}
\hline Test & Criterion & Test method & Comments \\
\hline UCS (soaked) & $350 \mathrm{kPa}^{18}$ & ASTM $^{12}$ & $\begin{array}{l}\text { All samples tested were } 100 \mathrm{~mm} \text { in diameter } \\
\text { and } 100 \mathrm{~mm} \text { high }\end{array}$ \\
\hline Permeability & $\begin{array}{l}<10^{-9} \mathrm{~m} / \mathrm{s} \text { (as for } \\
\text { clay liners and } \\
\text { cut-off walls) }\end{array}$ & Flow pump method ${ }^{13}$ & $\begin{array}{l}\text { Samples were } 100 \mathrm{~mm} \text { in diameter and } 100 \mathrm{~mm} \\
\text { high. Test performed in flexible wall } \\
\text { permeameters using a hydraulic gradient } \\
\text { of } 10-40\end{array}$ \\
\hline $\begin{array}{l}\text { Durability: } \\
\text { Wet-dry } \\
\text { Freeze-thaw }\end{array}$ & $\begin{array}{l}\text { Pass ASTM tests } \\
\text { of } 12 \text { cycles }\end{array}$ & $\operatorname{ASTM}^{14,15}$ & $\begin{array}{l}\text { Samples were } 100 \mathrm{~mm} \text { in diameter and } 60 \mathrm{~mm} \\
\text { high. Freeze-thaw temperature used was } \\
-10^{\circ} \mathrm{C} \text { instead of specified }-20^{\circ} \mathrm{C}\end{array}$ \\
\hline Leachability & $\begin{array}{l}\text { Leachate } \\
\text { concentrations } \leqslant 50 \\
\text { times greater than } \\
\text { drinking water } \\
\text { standards } 19\end{array}$ & $\begin{array}{l}\text { Tests applied were TCLP } \\
\text { and NRA. }{ }^{16} \text { Analysis of heavy metals } \\
\text { was carried out using an atomic } \\
\text { absorption spectrophotometer. } \\
\text { Analysis of organics was carried out } \\
\text { using low detection level GC/FID } \\
\text { down to } 0.01 \mathrm{mg} / \mathrm{l}\end{array}$ & $\begin{array}{l}\text { In the TCLP test the extraction fluid was a } \\
\text { dilute acid solution with } \mathrm{pH} \text { of } 4.9 \pm 0.2 \\
\text { In the NRA test the extraction fluid was } \\
\text { deionised water carbonated down to a } \mathrm{pH} \text { of } \\
5.5 \pm 0.2\end{array}$ \\
\hline Leachate $\mathrm{pH}$ & $7-11^{20}$ & $\begin{array}{l}\text { Performed on the leachates at the } \\
\text { end of leaching tests above }\end{array}$ & \\
\hline $\begin{array}{l}\text { Microstructural } \\
\text { analyses: XRD } \\
\text { and SEM }\end{array}$ & & & $\begin{array}{l}\text { For XRD Philips PW I050 Vertical } \\
\text { Diffractometer was used } \\
\text { For SEM a Leica Stereocam } 430 \text { machine was } \\
\text { used on gold-coated samples }\end{array}$ \\
\hline
\end{tabular}

\begin{tabular}{|lcc|}
\hline Mix & Made ground & Sand and gravel \\
\hline A & 2368 & 4362 \\
B & 5406 & 4081 \\
C & 3763 & 5832 \\
D & 4619 & 3971 \\
E & 3908 & 3964 \\
F & 4068 & 2964 \\
G & 2969 & 3008 \\
Bo & 3333 & 6090 \\
Co & 4106 & 5321 \\
Do & 1486 & 1218 \\
Eo & 1752 & 2432 \\
& & \\
\hline Table 5. Average UCS results (in kPa) at 5 years
\end{tabular}

However, mixes B and D do not contain the highest amount of pozzolanic materials, and this implies that more complex interactions may be involved.

About $10 \%$ of the total samples tested showed a low strength value of 1040-1750 kPa. In some cases these values were inconsistent with the remaining UCS of the same mix samples, but they were still used in the average values presented in Table 5. In some of these cases this observation was associated with the presence of extraneous objects, but in others this leads to the conclusion that in some areas the grout was inconsistently mixed with the soil. However, all the UCS values are well above the design value of $350 \mathrm{kPa}$ and well above the required target values for most other geotechnical or geoenvironmental applications.

UCS testing was also performed on a large number of samples at the end of the permeability tests, and hence these tested

samples had been subjected to water permeation of up to five pore volumes. The UCS was consistent with that of samples that had not been subjected to permeation, and this shows that the slow permeation of water through the treated soil does not affect its UCS values. This is contrary to what was postulated previously based on the results of a single test. ${ }^{2}$

\subsection{Permeability}

The permeability ${ }^{13}$ was measured in flexible-wall permeameters, on samples $100 \mathrm{~mm}$ in diameter and $100 \mathrm{~mm}$ high, using flow rates ranging from 0.0008 to $0.03 \mathrm{ml} / \mathrm{min}$. The variability of the flow rate depended on the permeability of the sample, and was also due to the fact that two samples were run simultaneously from the same flow pump. Up to three samples were tested for each mix, and the average 5-year permeability results are presented in Table 6 with average variations of $\pm 40 \%$. Measured permeabilities ranged from $0 \cdot 21 \times 10^{-9}$ to $3.2 \times 10^{-9} \mathrm{~m} / \mathrm{s}$. The average permeabilities of all the made-ground and sand and gravel single-column mixes were similar at $0.78 \times 10^{-9}$ and $0.72 \times 10^{-9} \mathrm{~m} / \mathrm{s}$ respectively. These results show no trends or correlation with the grout constituents or content apart from the fact that mix G, which contained bentonite, had the lowest permeability, as would be expected.

The average permeabilities of the made ground and sand and gravel overlap-column mixes were $1.22 \times 10^{-9} \mathrm{~m} / \mathrm{s}$ and $0 \cdot 85 \times 10^{-9} \mathrm{~m} / \mathrm{s}$ respectively and again show no trend. The average permeabilities of the made ground overlap-column mixes were higher than those of the single-column mixes. The hypothesis from the UCS results regarding the make-up of the overlap columns is probably the cause of the higher permeabilities of mixes Do and Eo compared with those of mixes $\mathrm{D}$ and $\mathrm{E}$. 


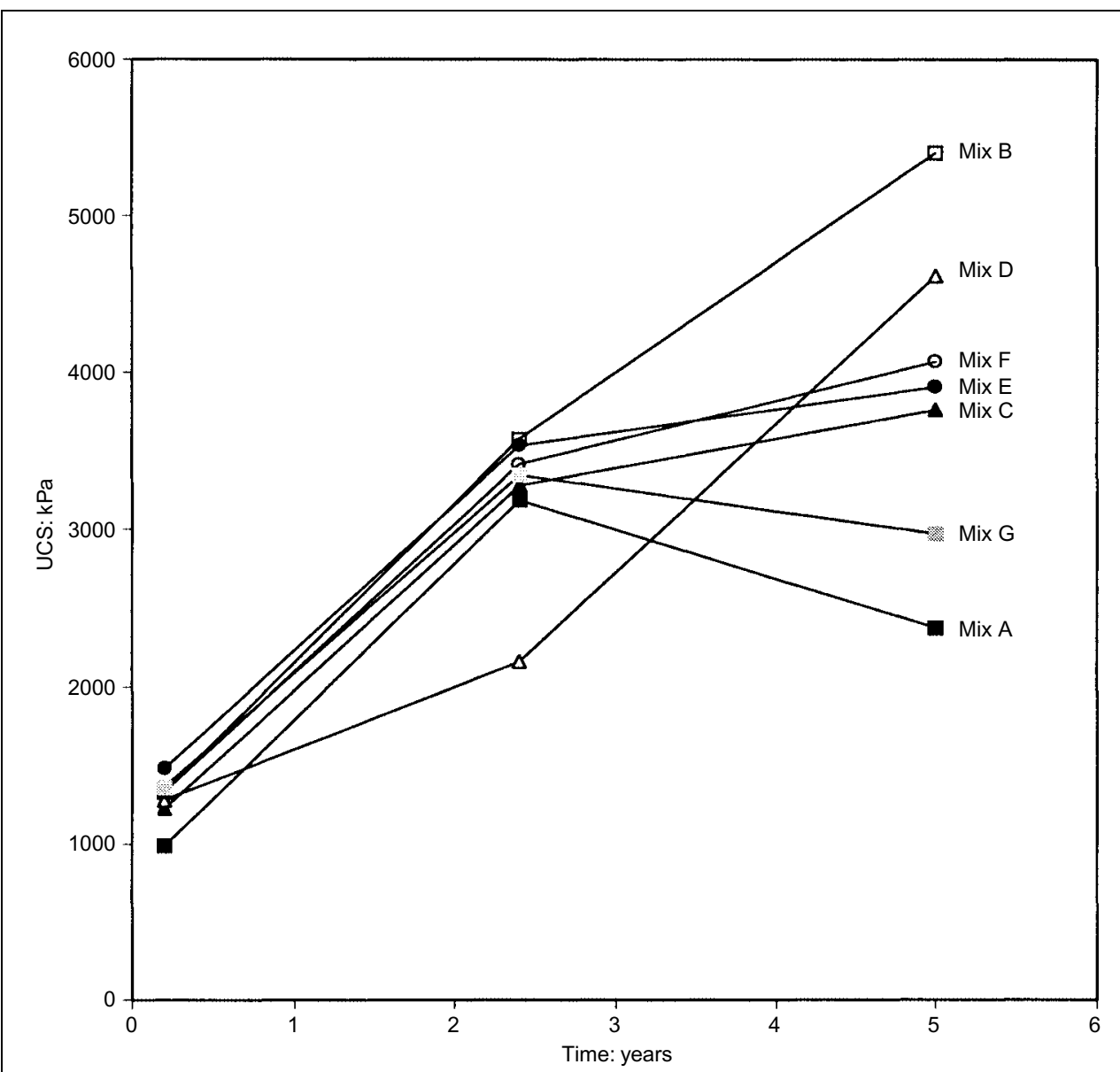

(a)

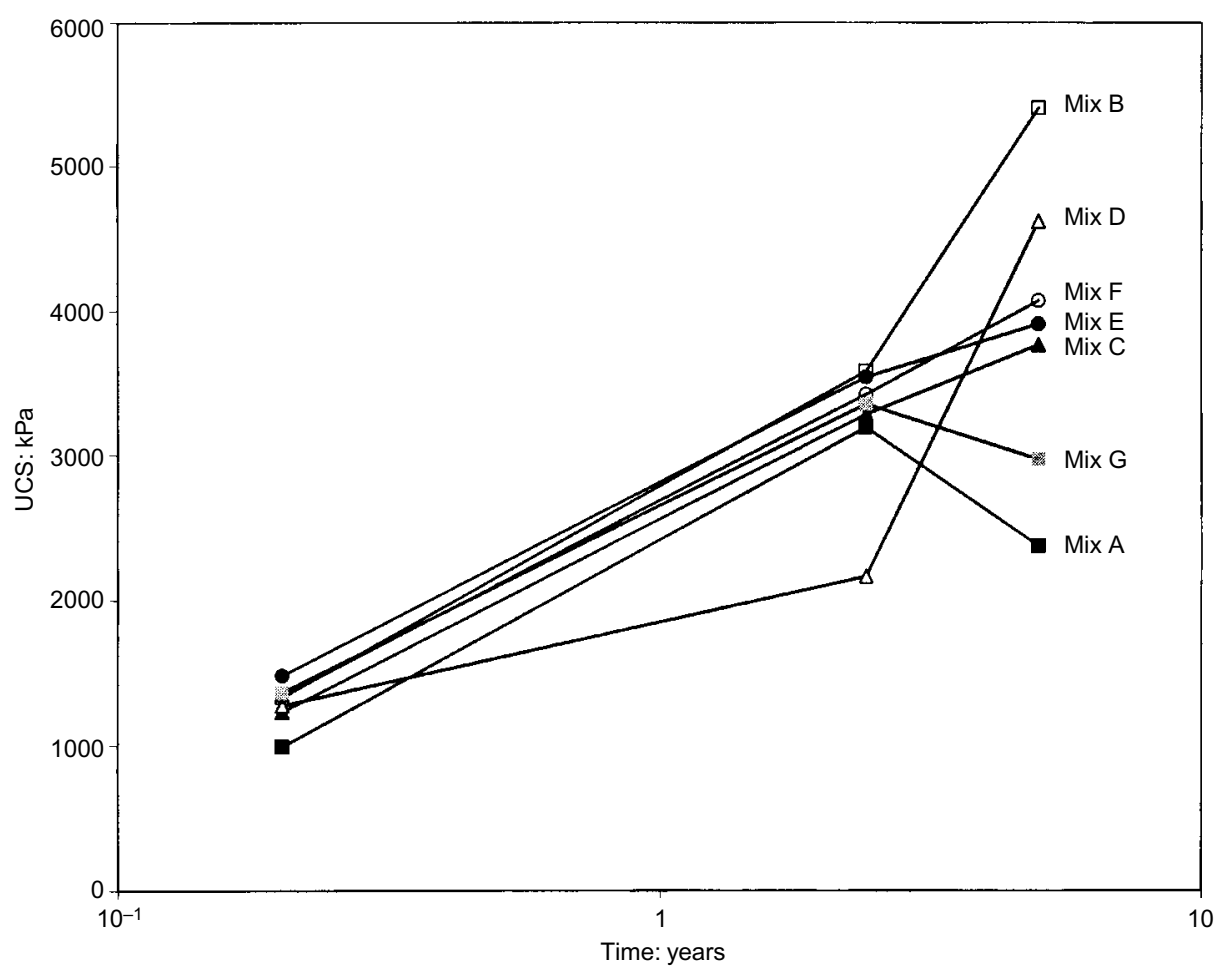

(b)
The permeability values are in the region of the specified design value of $10^{-9} \mathrm{~m} / \mathrm{s}$, with $30 \%$ of them being slightly higher. Options that could improve the permeability performance include additional compaction or a higher grout content. However, consideration needs to be given to the applicability of such a low design value to the specific treatment applied. It is feasible that this design value, applied to cutoff walls that traditionally offer only physical encapsulation, is too stringent for a treatment that also offers chemical encapsulation.

The time-related performance of the made ground singlecolumn mixes is shown in Fig. 6. Whereas there was a general clear reduction in permeability at $2 \cdot 4$ years compared with $0 \cdot 2$ years, at 5 years there is no further change, with the average permeability being very similar to that at $2 \cdot 4$ years. The permeability of four of the mixes (A, B, F and G) increased, whereas that of the other three (C, D and E) decreased in both cases by up to four times at 5 years compared with that at $2 \cdot 4$ years. Compared with $0 \cdot 2$ years, the permeabilities at 5 years mainly decreased, by up to three times, apart from mixes $\mathrm{B}$ and $\mathrm{F}$, which increased by up to seven times. Given that the permeability values are quite small, being in the region of $10^{-9} \mathrm{~m} / \mathrm{s}$, these changes are also generally quite small. This varied response could be the result of a combination of continued hydration of the cementitious constituents, causing the permeability to decrease, and the long-term interaction between the contaminants and the soilgrout matrix, which in this case has caused an increase 


\begin{tabular}{|lcc|}
\hline Mix & Made ground & Sand and gravel \\
\hline A & 0.86 & 1.23 \\
B & 1.25 & 0.66 \\
C & 0.34 & 0.35 \\
D & 0.51 & 0.65 \\
E & 0.31 & 0.92 \\
F & 1.85 & 0.95 \\
G & 0.31 & 0.30 \\
Bo & 0.93 & 0.21 \\
Co & 0.23 & 0.28 \\
Do & 1.40 & 1.60 \\
Eo & 3.20 & 1.30 \\
& & \\
Table 6. Average permeability $\left(\times 10^{-9} \mathrm{~m} / \mathrm{s}\right)$ at 5 years
\end{tabular}

in the permeability. Hence at 5 years there is no correlation between the mix constituents and their permeability, which was evident up to $2 \cdot 4$ years, when mixes $\mathrm{B}, \mathrm{F}$ and $\mathrm{G}$ maintained the lowest permeabilities.

\subsection{Wet-dry and freeze-thaw durability}

The samples tested for durability were $100 \mathrm{~mm}$ in diameter and $60 \mathrm{~mm}$ high, and three samples were used for each of the wetdry, ${ }^{14}$ freeze-thaw ${ }^{15}$ and control cycles. The wet-dry durability results in terms of the percentage average cumulative dry mass loss are presented in Table 7 for $0 \cdot 2,2 \cdot 4$ and 5 years. The table clearly shows that at 5 years the resistance of all the tested samples to wet-dry cycles is very high, as it was at 0.2 and 2.4 years, with a maximum cumulative dry mass loss of $2 \%$. The negative values indicate that the test samples performed better-that is, deteriorated less-than the control samples.

The corresponding freeze-thaw durability results are shown in Table 8 . The samples at 5 years were subjected to exactly the same test conditions as the samples at $2 \cdot 4$ years ( 12 cycles at $-10^{\circ} \mathrm{C}$ ); the samples at $0 \cdot 2$ years were subjected to six cycles at $-10^{\circ} \mathrm{C}$ followed by six cycles at $-20^{\circ} \mathrm{C}$. The table shows that the performance at 5 years is variable, with 12 out of the 22 tested mixes failing the test; there was no obvious correlation with grout constituents or content. More made ground mixes survived than sand and gravel, with mix $\mathrm{C}$ being the only mix that survived in both soil types.

The freeze-thaw durability of the made ground overlapcolumn mixes was consistently better than that of the singlecolumn mixes. This shows that the increased grout content in the overlap columns has improved their resistance to freezethaw cycles. Hence the earlier hypothesised structure of the overlap columns has not had a detrimental effect on the

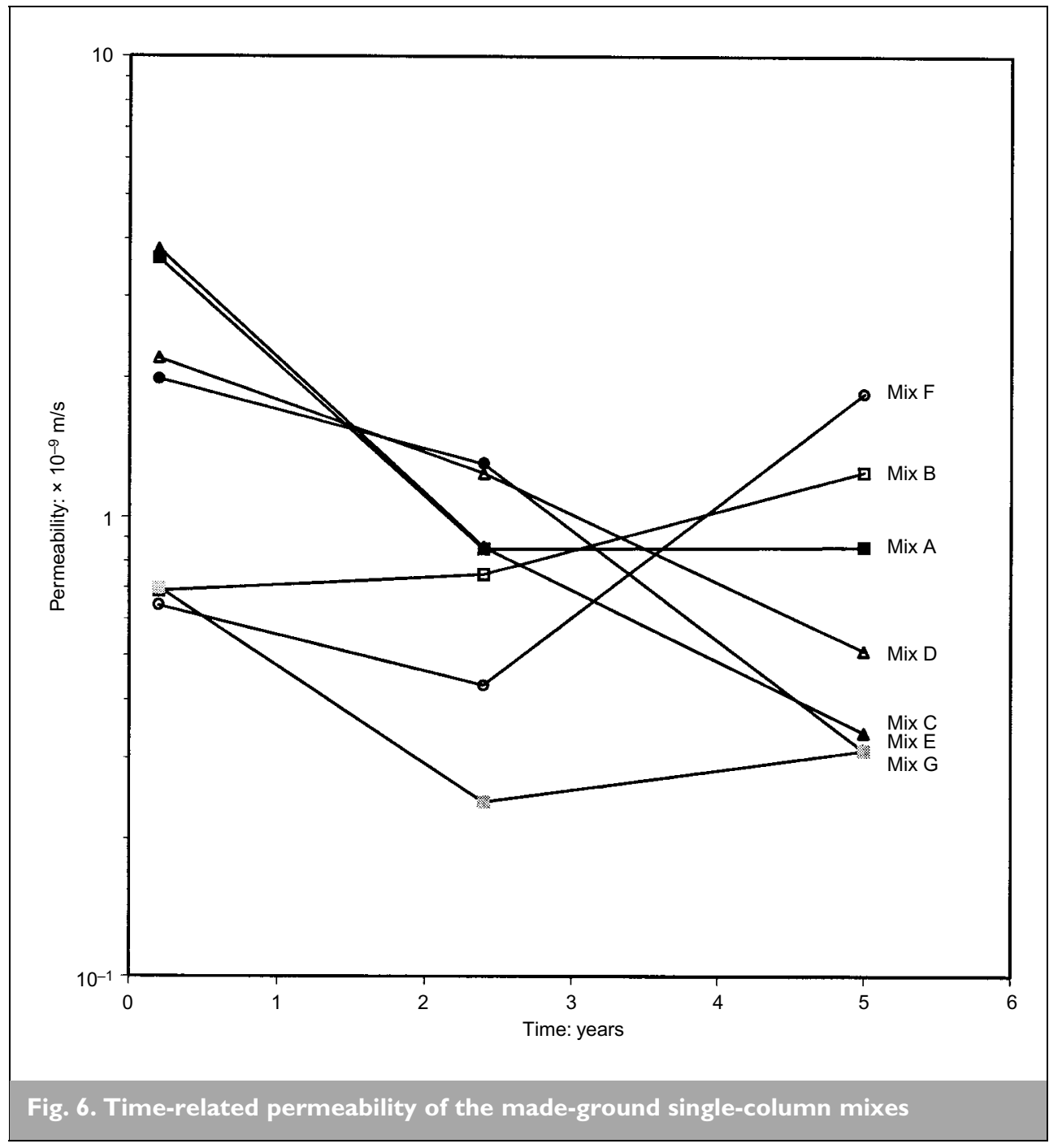

freeze-thaw performance. It is likely, however, that an even better performance would be obtained if effective mixing had taken place in the overlap columns. Three out of the four sand and gravel overlap column mixes performed worse than the corresponding single-column mixes, which is opposite to the behaviour observed with the made ground and is consistent with the hypothesised structure of the overlap columns.

In some cases a large variation was observed in the durability results at 5 years, even when the samples came from the same core. This can be attributed in some cases to the presence of extraneous materials but can generally be attributed to ageing. This was observed in both the made ground and sand and gravel, although to a lesser extent in the sand and gravel, since some of the extraneous material from the made ground was dragged down into the sand and gravel by the auger mixing process. It is clear that in terms of 


\begin{tabular}{|lcccc|}
\hline Mix & $\begin{array}{c}\text { Made ground, } 0.2 \\
\text { years: \% }\end{array}$ & $\begin{array}{c}\text { Made ground, 2.4 } \\
\text { years: \% }\end{array}$ & $\begin{array}{c}\text { Made ground, } 5 \\
\text { years: \% }\end{array}$ & $\begin{array}{c}\text { Sand and gravel, } 5 \\
\text { years: \% }\end{array}$ \\
\hline A & -1.5 & 0.33 & 0.05 & $\mathrm{n} / \mathrm{t}$ \\
B & 1.8 & 0.05 & -0.05 & -0.01 \\
C & 1.9 & 0.01 & -0.01 & -0.09 \\
D & -1.2 & 0.06 & 0.55 & 0.06 \\
E & 0.4 & 0.01 & -0.63 & 0.11 \\
F & 0.5 & 0.02 & -0.03 & 2.00 \\
G & -0.4 & -0.03 & -0.80 & $\mathrm{n} / \mathrm{t}$ \\
Co & $\mathrm{n} / \mathrm{t}$ & $\mathrm{n} / \mathrm{t}$ & 0.05 & -0.11 \\
Eo & $\mathrm{n} / \mathrm{t}$ & $\mathrm{n} / \mathrm{t}$ & 0.03 & 0.05 \\
\hline
\end{tabular}

$\mathrm{n} / \mathrm{t}$ : not tested

Table 7. Wet-dry durability in percentage average cumulative dry mass loss

\begin{tabular}{|c|c|c|c|c|}
\hline Mix & $\begin{array}{c}\text { Made ground, } 0 \cdot 2 \\
\text { years: } \%\end{array}$ & $\begin{array}{c}\text { Made ground, } 2 \cdot 4 \\
\text { years: } \%\end{array}$ & $\begin{array}{l}\text { Made ground, } 5 \\
\text { years: \% }\end{array}$ & $\begin{array}{c}\text { Sand and gravel, } 5 \\
\text { years: } \%\end{array}$ \\
\hline A & $27 \cdot 4$ & Fac $8(35 \cdot 9)$ & $\operatorname{Fac} 9(36.0)$ & $\mathrm{n} / \mathrm{t}$ \\
\hline B & $27 \cdot 1$ & Fac II (32·3) & $17 \cdot 3$ & Fac II $(32 \cdot 0)$ \\
\hline C & $24 \cdot 4$ & 1.95 & $8 \cdot 4$ & $6 \cdot 2$ \\
\hline $\mathrm{D}$ & $27 \cdot 0$ & Fac $9(39.9)$ & $\operatorname{Fac} 6(30 \cdot 1)$ & $13 \cdot 7$ \\
\hline$E$ & $11 \cdot 4$ & 1.48 & $\operatorname{Fac} 9(3 \mid \cdot 1)$ & Fac $10(30 \cdot 8)$ \\
\hline$F$ & 10.9 & Fac II (3I·4) & Fac $12(30 \cdot 8)$ & Fac $7(32.8)$ \\
\hline G & -0.4 & 0.66 & $25 \cdot 1$ & Fac $10(45 \cdot 4)$ \\
\hline Bo & $\mathrm{n} / \mathrm{t}$ & $\mathrm{n} / \mathrm{t}$ & $10 \cdot 8$ & Fac $8(3 \mid \cdot 3)$ \\
\hline Co & $\mathrm{n} / \mathrm{t}$ & $n / t$ & $2 \cdot 6$ & Fac $10(4 \mid \cdot 0)$ \\
\hline Do & $n / t$ & $n / t$ & Fac $7(39 \cdot 1)$ & $28 \cdot 5$ \\
\hline Eo & $n / t$ & $\mathrm{n} / \mathrm{t}$ & $16 \cdot 2$ & Fac II $(30.7)$ \\
\hline
\end{tabular}

n/t: not tested. Fac: failed at cycle, with percentage mass loss in brackets afterwards

Table 8. Freeze-thaw durability in percentage average cumulative dry mass loss

presented in the same tables but are discussed separately below.

\subsection{Leachate $\mathrm{pH}$}

The NRA ${ }^{17}$ leachate $\mathrm{pH}$ values at 5 years, based on the average of two tests with an average variation of $\pm 0 \cdot 3$, are shown in Table 9. These leachate $\mathrm{pH}$ values are quite high, and are at the high end of the design range. The average NRA leachate $\mathrm{pH}$ values of the made ground single and overlap column mixes were $10 \cdot 4$ and $11 \cdot 1$ respectively. The higher latter values can be associated with the increased grout content in the overlap column mixes. The NRA leachate $\mathrm{pH}$ values of the sand and gravel mixes are similar to those of the made-ground mixes.

Since in the earlier investigations only the TCLP $^{16}$ leaching test was performed at $0 \cdot 2$ years, and on made ground singlecolumn mixes only, these mixes were tested in the same way at 5 years for direct comparison purposes. The time-related performance of the TCLP leachate $\mathrm{pH}$ of made ground single-column

durability performance the samples have generally slightly weakened over time, although the strength has generally increased.

Although more than half the samples failed the freeze-thaw durability test, it has recently been stated that freeze-thaw testing should be applicable in the UK only to the top $1 \mathrm{~m}$ of the treated ground. ${ }^{1}$ However, it has also been proposed that such short-term exposure to severe environmental conditions is representative of long-term exposure to less severe conditions $^{24}$ and hence represents a predictive test for longterm durability performance under real environmental conditions. This correlation is yet to be validated.

At 5 years, with the exception of mix B, the made ground single-column mixes either behaved roughly the same or deteriorated compared with the behaviour at $2 \cdot 4$ years. Mixes C, E and G, which performed best at $2 \cdot 4$ years, deteriorated at 5 years, with mix E failing the test. Hence on average there is a general slight deterioration in the behaviour at 5 years compared with that at $2 \cdot 4$ years. Mixes C and G are the only two mixes that survived throughout.

The leachate $\mathrm{pH}$ and leachate concentration results are mixes is presented in Fig. 7. This shows a continuous decrease in leachate $\mathrm{pH}$ associated with continued carbonation, but at 5 years the $\mathrm{pH}$ values have reached background values and hence are unlikely to reduce any further.

The 5-year average NRA leachate $\mathrm{pH}$ of the made ground single-column mixes at $10 \cdot 4$ is higher than the average TCLP leachate $\mathrm{pH}$ value of 6.9. This could be attributed partially to the initially higher $\mathrm{pH}$ of the extraction fluid in the NRA test of 5.5 compared with 4.9 in the TCLP test. This clearly demonstrates how different leaching tests produce different results, and how it is important to ensure that the appropriate relevant test is used.

\subsection{Leachability}

The TCLP ${ }^{16}$ leaching test was originally adopted by the US Environmental Protection Agency in 1986 to determine whether a particular waste meets the applicable technologybased treatment standards to be land-disposed, but it is also widely used to evaluate the effectiveness of stabilisation. ${ }^{25}$ The use of a dilute acid solution with $\mathrm{pH}$ of $4.9 \pm 0 \cdot 2$ as the extraction fluid simulates leaching conditions in a municipal waste site, where organic acids can be present from waste decomposition. However, such severe leaching conditions in 


\begin{tabular}{|lrccrrr|}
\hline $\begin{array}{l}\text { Made ground } \\
\text { Mix }\end{array}$ & $\mathrm{pH}$ & Copper & Zinc & Nickel & TPH & Mineral oil \\
\hline $\mathrm{A}$ & 9.5 & 0.20 & $<0.005$ & 0.13 & 0.012 & 0.012 \\
$\mathrm{~B}$ & 11.0 & 1.18 & $<0.005$ & $<0.02$ & 0.020 & 0.014 \\
$\mathrm{C}$ & 11.3 & 1.36 & $<0.005$ & 0.09 & 0.023 & 0.014 \\
$\mathrm{D}$ & 11.3 & 1.42 & $<0.005$ & 0.07 & 0.020 & 0.012 \\
$\mathrm{E}$ & 8.3 & 0.51 & $<0.005$ & 0.14 & 0.065 & 0.029 \\
$\mathrm{~F}$ & 10.2 & 0.36 & $<0.005$ & 0.13 & 0.024 & 0.016 \\
$\mathrm{G}$ & 11.2 & 0.49 & $<0.005$ & 0.12 & 0.039 & 0.016 \\
Bo & 11.2 & 0.31 & 0.02 & 0.32 & 0.034 & 0.017 \\
Co & 11.2 & 0.38 & 0.02 & 0.42 & 0.023 & 0.016 \\
Do & 10.7 & 0.40 & $<0.005$ & 0.31 & 0.023 & 0.016 \\
Eo & 11.2 & 0.45 & $<0.005$ & 0.31 & 0.034 & 0.021 \\
DWS & & 3 & 5 & 0.05 & & 0.010 \\
Untreated & 7.3 & 4.97 & 7.10 & 3.89 & 0.060 & 0.045 \\
site soil & & & & & & \\
\hline
\end{tabular}

The average 5-year NRA leachate concentration of mineral oil (up to $0.054 \mathrm{mg} / \mathrm{l}$ ) is up to six times the drinking water standard, although most of the values are only slightly higher than the drinking water standard of $0.01 \mathrm{mg} / \mathrm{l}$. The total petroleum hydrocarbons (TPH) concentrations show that about $50 \%$ of these are due to the presence of the mineral oil fractions $\left(C_{20}-C_{40}\right)$. The other $50 \%$ was due to the lighter diesel fractions $\left(\mathrm{C}_{10}-\mathrm{C}_{20}\right)$, with no concentrations from the lighter gasoline fractions $\left(<\mathrm{C}_{10}\right)$.

\begin{tabular}{lcccccc} 
Mix & $\mathrm{pH}$ & Copper & Zinc & Nickel & TPH & Mineral oil \\
\hline $\mathrm{A}$ & 10.3 & 0.51 & $<0.005$ & 0.30 & 0.020 & 0.014 \\
$\mathrm{~B}$ & 11.2 & 1.78 & $<0.005$ & 0.04 & 0.017 & 0.017 \\
$\mathrm{C}$ & 11.3 & 1.73 & $<0.005$ & 0.05 & 0.020 & 0.020 \\
$\mathrm{D}$ & 11.3 & 0.87 & $<0.005$ & 0.17 & 0.013 & 0.013 \\
$\mathrm{E}$ & 10.0 & 0.21 & $<0.005$ & 0.11 & 0.012 & 0.012 \\
$\mathrm{~F}$ & 9.4 & 0.15 & $<0.005$ & 0.21 & 0.021 & 0.014 \\
$\mathrm{G}$ & 10.5 & 0.25 & $<0.005$ & 0.01 & 0.023 & 0.016 \\
Bo & 10.9 & 0.22 & $<0.005$ & 0.37 & 0.019 & 0.011 \\
Co & 11.2 & 0.50 & 0.07 & 0.32 & 0.036 & 0.011 \\
Do & 11.3 & 0.23 & $<0.005$ & 0.26 & 0.028 & 0.012 \\
Eo & 11.4 & 0.33 & $<0.005$ & 0.24 & 0.140 & 0.054 \\
DWS & & 3 & 5 & 0.05 & & 0.010 \\
Untreated & 7.7 & 2.10 & 2.27 & 2.43 & 0.093 & 0.068 \\
site soil & & & & & & \\
\hline
\end{tabular}

TPH: total petroleum hydrocarbon, DWS: Drinking Water Standard ${ }^{19}$

the test are considered by some to represent a worst-case scenario for leaching conditions in stabilisation systems. ${ }^{26}$ The $\mathrm{NRA}^{17}$ leaching test, by contrast, was developed in the UK in 1994 to simulate the leaching of contaminants from the ground by acidic rainwater. As the NRA leaching test has been adopted by the UK Environment Agency, and is likely to be more appropriate to the problem considered here, it is investigated here in more detail. However, in order to facilitate comparison with the earlier results, in which only the TCLP test was carried out, the TCLP test was also performed on some mixes.

The average NRA ${ }^{17}$ leachate concentrations of copper, zinc, nickel, mineral oil and total petroleum hydrocarbon (TPH) are presented in Table 9, with a variability of up to $\pm 30 \%$. Lead and cadmium concentrations were also measured but were found to be below their detection levels, which are also below their drinking water standards. ${ }^{19}$ Table 9 shows that the concentrations of copper (up to $1.78 \mathrm{mg} / \mathrm{l}$ ) and zinc (up to $0.07 \mathrm{mg} / \mathrm{l}$ ) are below their drinking water standards. However, the nickel concentration (up to $0.42 \mathrm{mg} / \mathrm{l}$ ) is up to nine times higher than its drinking water standard.
The average 5-year TCLP leachate concentrations of copper, zinc and lead, at $0 \cdot 2$ and 5 years, based on two tests with an average variability of $\pm 80 \%$, are presented in Table 10. Although the leached concentrations at $0 \cdot 2$ years were well below their drinking water standards, ${ }^{19}$ this is not the case at 5 years. The copper, zinc and lead concentrations increased by up to 3, 104 and 82 times respectively. The copper and zinc concentrations are, however, still below their drinking water standards, whereas the lead concentrations are up to 50 times higher. This increase in concentration can be associated with the reduction in $\mathrm{pH}$, which has generally caused the solubility of the heavy metals to increase.

According to the set criterion for the leachate concentrations, of up to 50 drinking water standards, all the above concentrations of heavy metals and organic compounds from both leaching tests are acceptable. However, recent standards have been produced by the UK Environment Agency ${ }^{27}$ that specify upper-limit concentrations for groundwater that are lower than drinking water standards. Hence acceptable concentrations will need to be assessed in terms of the appropriate applicable standards.

A comparison of the NRA leachate concentrations of copper and zinc in the made ground at 5 years (Table 9) with the corresponding TCLP concentrations (Table 10) shows that in the former the copper concentrations are similar but the zinc and lead concentrations are much lower. This can be attributed to the higher leachate $\mathrm{pH}$ values of the former. The different 


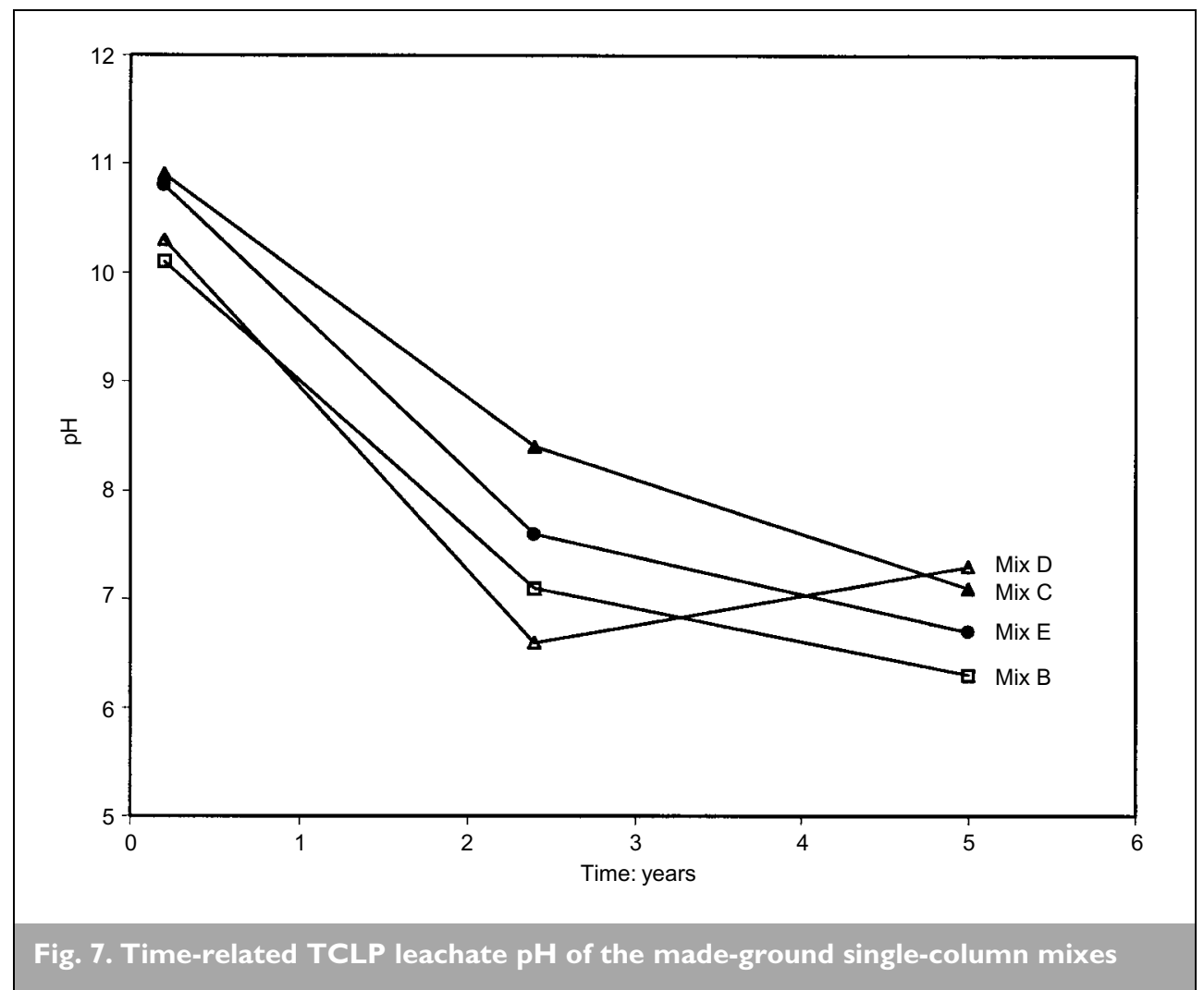

solubility of these organic compounds, a high level of heterogeneity in the contaminant concentrations in the site soils would be expected, and this could explain the very few high leached concentrations of TPH. This could also lead to the conclusion that the treatment is less effective for high organic concentrations. This is the subject of further investigation with the use of model contaminated soils.

The possibility of an increase in the leaching potential due to the presence of contaminants in the PFA (heavy metals) and cement (mineral oils from contamination during manufacture) has not been investigated yet, but this increase is expected to be minimal owing to the insignificant level of these

results from the two tests emphasise the importance of using tests relevant to the conditions encountered on the specific site.

Two NRA leaching tests were also performed on each of the original untreated site soils. Some of the contaminant concentrations are shown at the bottom of Fig. 9. The concentrations of lead and cadmium, which are below detection levels in the 5-year samples, are $0.39 \mathrm{mg} / \mathrm{l}$ and $0.22 \mathrm{mg} / 1$ in the made ground and $0.33 \mathrm{mg} / 1$ and $0.18 \mathrm{mg} / 1$ in the sand and gravel. It is clear from these results that the concentrations of heavy metals leached from the untreated soils are much higher than those leached from the treated soils. They range from being slightly higher to 350 times higher than the highest concentrations in the treated soil leachates. The leachate concentrations of mineral oil and TPH in the untreated soils are on average up to four times higher than the average of those of the treated soils. However, the TPH concentrations in the untreated soil leachates are lower than the highest values in the treated soil leachates, those being of mixes $\mathrm{E}$ and Eo. Owing to the extremely low contaminants compared with those present in the site soils.

Leachates from the flow-through permeability tests, which contained up to five pore volumes of leachate, were analysed for the five heavy metals and also for their $\mathrm{pH}$, and typical results are presented in Table 11. The water permeated was the same as that used in the NRA leaching test. The results are the average of two values with variations of up to $\pm 16 \%$. In these tests the volume of the leachate produced was up to $400 \mathrm{ml}$, giving an extremely low liquid : solid ratio compared with those used in the NRA and TCLP leaching tests. However, the flow volume equivalent to five pore volumes is usually considered representative of long-term flow conditions through barriers or landfill liners. Concentrations of zinc in the made ground mixes and lead and cadmium in both soil mixes were all below detection levels, which were also below their drinking water standards. The concentrations of copper and nickel are high, and these concentrations need to be assessed in relation to critical leaching conditions in situ. The very low concentrations of lead, cadmium and zinc show that, for these

\begin{tabular}{|c|c|c|c|c|c|c|c|c|}
\hline \multirow[t]{2}{*}{ Mix } & \multicolumn{4}{|c|}{0.2 years } & \multicolumn{4}{|c|}{5 years } \\
\hline & $\mathrm{pH}$ & Copper & Zinc & Lead & $\mathrm{pH}$ & Copper & Zinc & Lead \\
\hline $\begin{array}{l}\text { B } \\
C \\
E \\
\text { DWs }\end{array}$ & $\begin{array}{l}10 \cdot 1 \\
10.9 \\
10.8\end{array}$ & $\begin{array}{l}0.24 \\
0.13 \\
0.31 \\
3\end{array}$ & $\begin{array}{c}0.23 \\
<0.005 \\
0.01 \\
5\end{array}$ & $\begin{array}{l}0.03 \\
0.04 \\
0.02 \\
0.05\end{array}$ & $\begin{array}{l}7 \cdot 4 \\
7 \cdot 6 \\
6 \cdot 8\end{array}$ & $\begin{array}{l}0.64 \\
0.59 \\
0.62 \\
3\end{array}$ & $\begin{array}{l}1 \cdot 14 \\
0.52 \\
0.85 \\
5\end{array}$ & $\begin{array}{l}2.48 \\
0.45 \\
0.66 \\
0.05\end{array}$ \\
\hline \multicolumn{9}{|c|}{ DWS: drinking water standard ${ }^{19}$} \\
\hline
\end{tabular}




\begin{tabular}{|c|c|c|c|c|}
\hline $\begin{array}{l}\text { Made ground } \\
\text { Mix }\end{array}$ & $\mathrm{PH}$ & Copper & Zinc & Nickel \\
\hline $\begin{array}{l}\text { B } \\
\text { C } \\
\text { D } \\
\text { Co } \\
\text { Do } \\
\text { Eo } \\
\text { DWS }\end{array}$ & $\begin{array}{l}9.1 \\
8.5 \\
9.1 \\
8.9 \\
8.4 \\
8.5\end{array}$ & $\begin{array}{c}10.85 \\
10.47 \\
10.80 \\
12.77 \\
8.96 \\
12.31 \\
3\end{array}$ & $\begin{array}{c}<0.005 \\
<0.005 \\
<0.005 \\
<0.005 \\
<0.005 \\
<0.005 \\
5\end{array}$ & $\begin{array}{l}10.91 \\
3.73 \\
4.50 \\
2.37 \\
0.13 \\
2.68 \\
0.005\end{array}$ \\
\hline \multicolumn{5}{|c|}{ Sand and gravel } \\
\hline Mix & $\mathrm{PH}$ & Copper & Zinc & Nickel \\
\hline $\begin{array}{l}\text { B } \\
\text { C } \\
\text { D } \\
\text { Co } \\
\text { Do } \\
\text { Eo } \\
\text { DWS }\end{array}$ & $\begin{array}{l}9.2 \\
8.4 \\
8.6 \\
8.4 \\
8.6 \\
9.0\end{array}$ & $\begin{array}{c}5 \cdot 71 \\
7 \cdot 10 \\
11 \cdot 13 \\
11 \cdot 24 \\
12 \cdot 77 \\
12 \cdot 69 \\
3\end{array}$ & $\begin{array}{c}0.165 \\
<0.005 \\
<0.005 \\
<0.005 \\
<0.005 \\
<0.005 \\
5\end{array}$ & $\begin{array}{l}1.97 \\
3.13 \\
2.58 \\
3.00 \\
2.97 \\
1.98 \\
0.005\end{array}$ \\
\hline
\end{tabular}

portlandite. Slight portlandite peaks are present, which is consistent with the high intensity of the $\mathrm{CaCO}_{3}$ peaks. Slight ettringite and calcium aluminate hydrate (C-A-H) peaks can also be seen, indicating that intermediate hydration products are still present. Calcium silicate hydrate (C-S-H), another hydration product, is undetectable by XRD as it is a poorly crystalline solid. There are slight peaks of alite and belite, indicating the presence of some unhydrated cement.

\section{Comparison of the} diffractograms in Figs 8 and 9 shows very similar results for the single and overlap column mixes. This is another observation heavy metals, the leaching conditions do not affect the concentration in the leachate. The $\mathrm{pH}$ values ranged between 8.0 and $9 \cdot 3$, which is lower than the values measured in the NRA leaching test. This shows that the alkalinity of the cementitious materials was less activated in the flowthrough leaching tests compared with the NRA agitation test.

\subsection{Microstructural analyses}

The 5-year XRD

diffractograms are shown in Figs 8(a) and (b) for all the made ground and sand and gravel single-column mixes respectively and in Figs 9(a) and (b) for all the made ground and sand and gravel overlap-column mixes respectively. Figs 8(a) and (b) show that the diffractograms of the seven single-column mixes are generally similar to one another in terms of the identified peaks and their intensity. The strongest peaks after those of quartz are of calcium carbonation, the latter forming as a result of the carbonation of

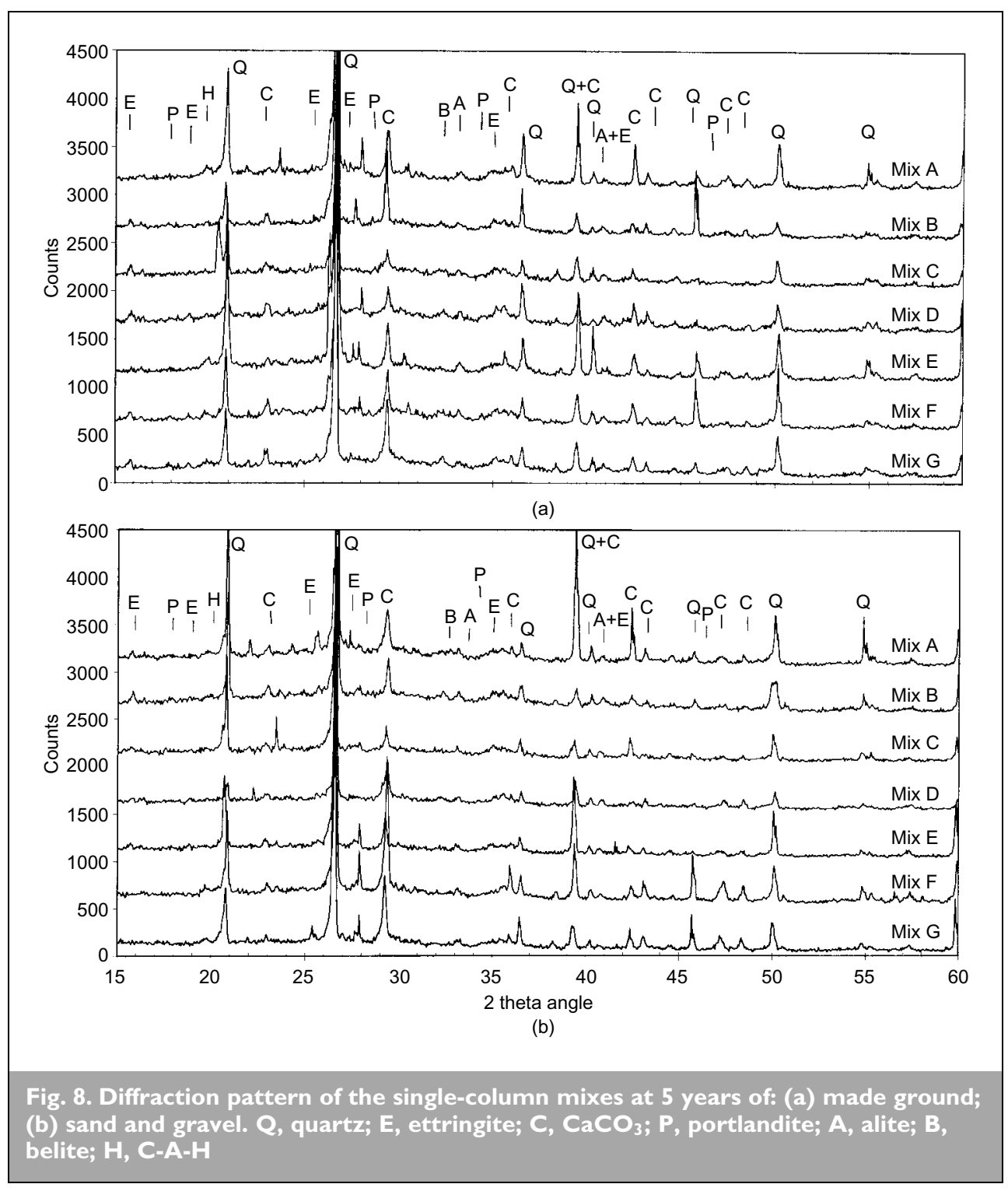




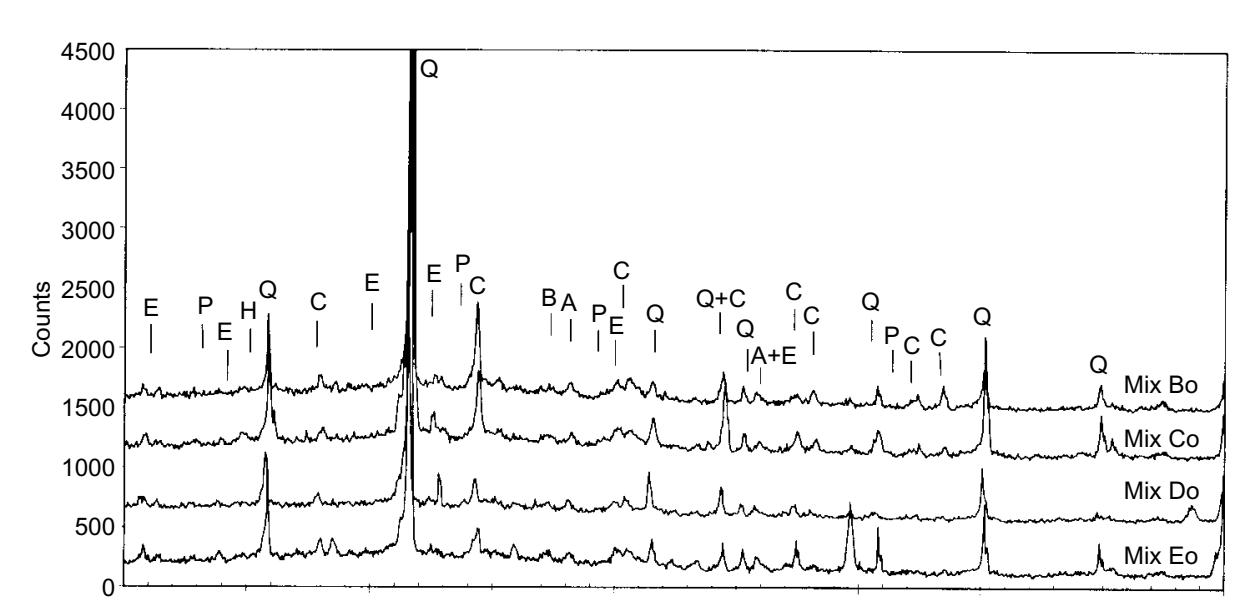

(a)

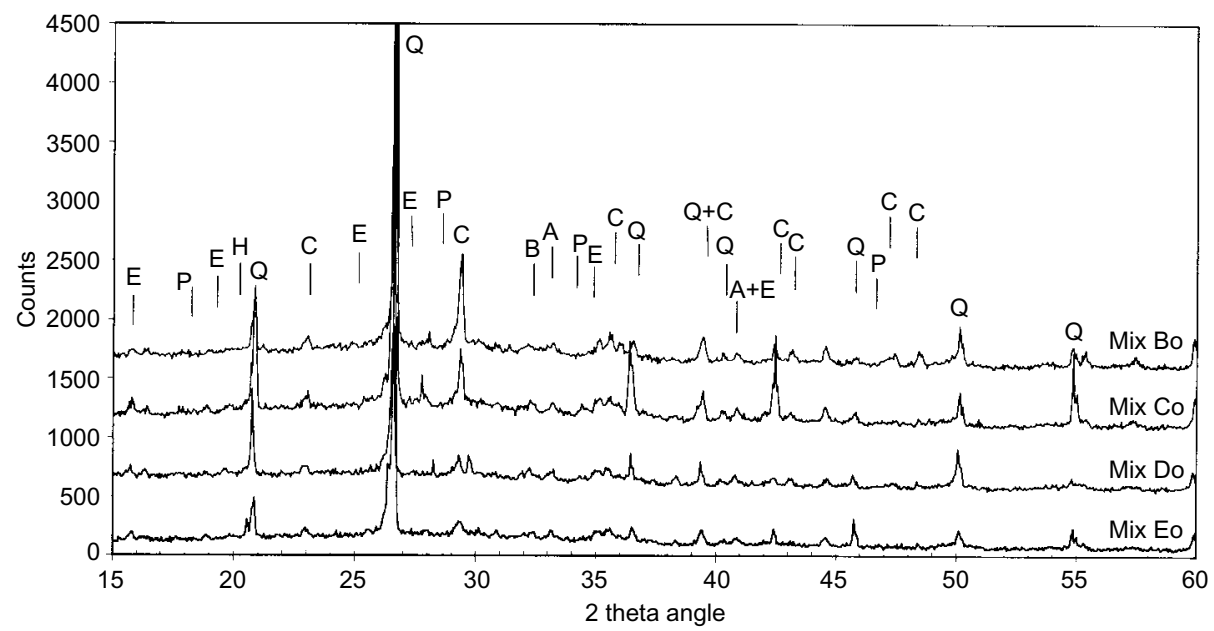

(b)

Fig. 9. Diffraction pattern of the overlap-column mixes at 5 years: (a) made ground: (b) sand and gravel. Q, quartz; E, ettringite; $\mathrm{C}, \mathrm{CaCO}_{3} ; \mathrm{P}$, portlandite; A, alite; $\mathrm{B}$, belite; H, C-A-H

similar. The micrographs generally show extensive fibrous gel-like material and limited voids, indicating advanced hydration processes compared with the corresponding micrograph of mix B at 1.2 years. $^{2}$ There was also less evidence of the plate-like crystals that are typical of $\mathrm{CH}$, monosulphate and C-A-H. This is expected at this advanced stage of hydration, when the presence of C-S-H dominates, and any hexagonal crystals of C-A-H are likely to be surrounded by C-S-H gel.

More sophisticated microstructural analyses, such as electron probe microanalysis, will need to be used to identify the form in which the contaminants are present within the solidified/ stabilised matrix, and to establish whether the contaminants are physically or chemical fixed. This the subject of an ongoing followup EPSRC project.

\section{GENERAL REMARKS}

(a) It is clear from the above discussion that mixing within the overlap columns was not very

supporting the hypothesis that the overlap-column mixes are most likely to be made up of single-column material, coated with grout.

Comparison between the XRD results of the made ground single-column mixes at 5 years and at $1 \cdot 2$ years $^{2}$ shows that there are generally more peaks present at 5 years. This is likely to be associated with a higher level of hydration and also with carbonation at 5 years. Both processes are likely to lead to a reduction in permeability, owing to the formation of hydration and carbonation products in the pores. This effect is clearly insignificant in the mixes that showed a permeability increase over time.

Typical SEM micrographs of the made ground and sand and gravel from the single and overlap column mixes at 5 years are shown in Figs 10(a) - (f). The crystalline phases identified in the XRD patterns are easily observed in the micrographs. Fig. 10 shows examples of needle-like ettringite crystals, the poorly crystalline gel and fibrous growth of C-S-H, and reacted and unreacted spherical PFA particles with surface hydration products.

The micrographs in Figs 10(c)-(f) are all of mix B and are all effective. To rectify this, additives to retard the setting of the grout can be used when installing the single columns to ensure that the overlap columns are easy to install and consist of a homogeneous mix. In addition, the percentage overlap between the columns can be reduced with more precise positioning and verticality control of the columns.

(b) The variability observed in the results is attributed to the presence of extraneous materials and the variable level of mixing of the grout with the soil. It is therefore recommended that, when testing soil-mixed stabilised/ solidified contaminated ground, a larger number of samples should be used than is usually specified in test methods. The specific number of samples that would be considered satisfactory would have to be site-specific. This will be influenced by the degree of variability within the soil, the quantity and type of extraneous objects present, and the effectiveness of the mixing process. The appropriate number of samples could perhaps be decided upon by the researcher if maximum allowable margins of errors are set for individual tests.

(c) There is generally an expected correlation between the strength and durability and strength and permeability of cement-treated soils. ${ }^{23}$ It would be expected that an increase in strength would cause an improved durability 


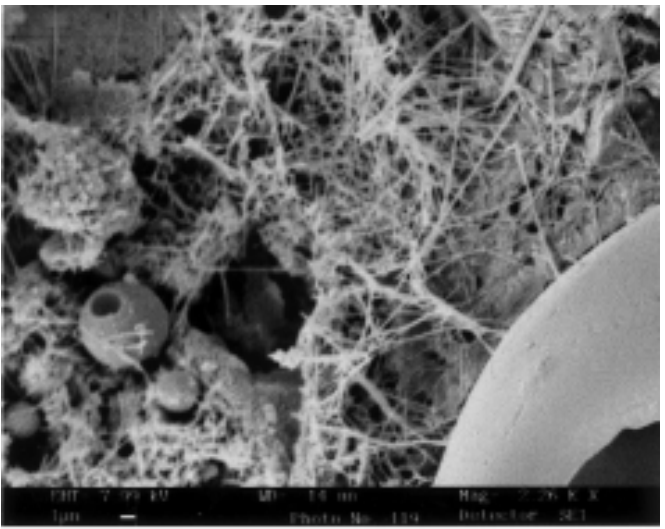

(a)

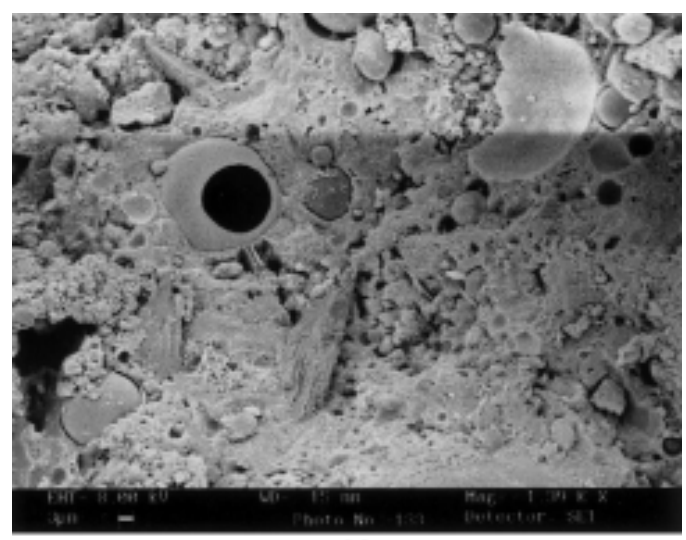

(c)

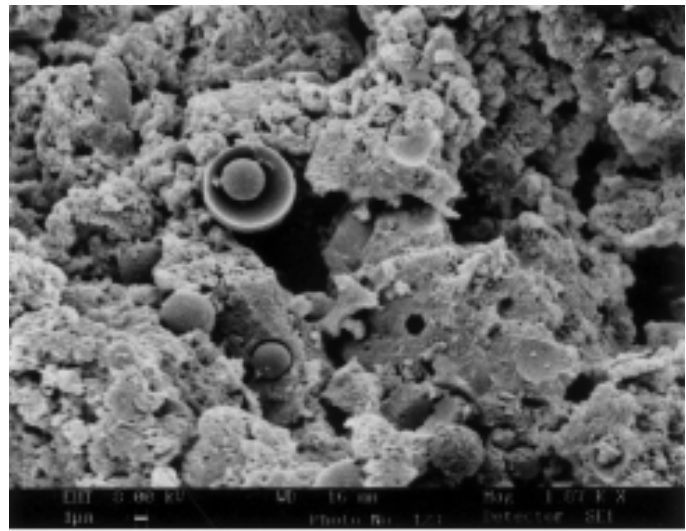

(e)

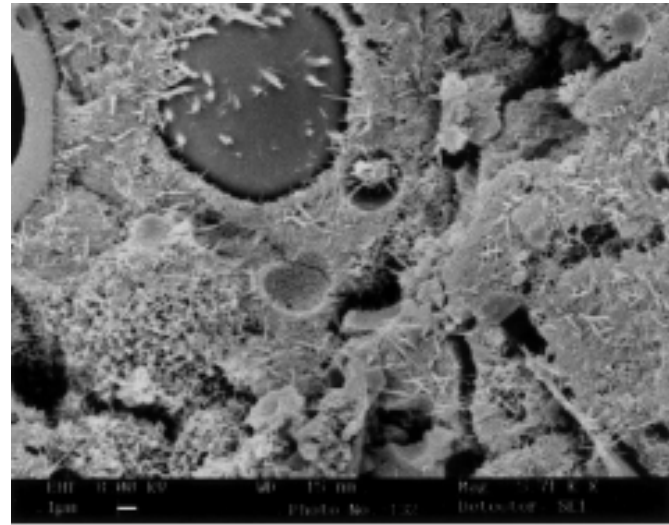

(b)

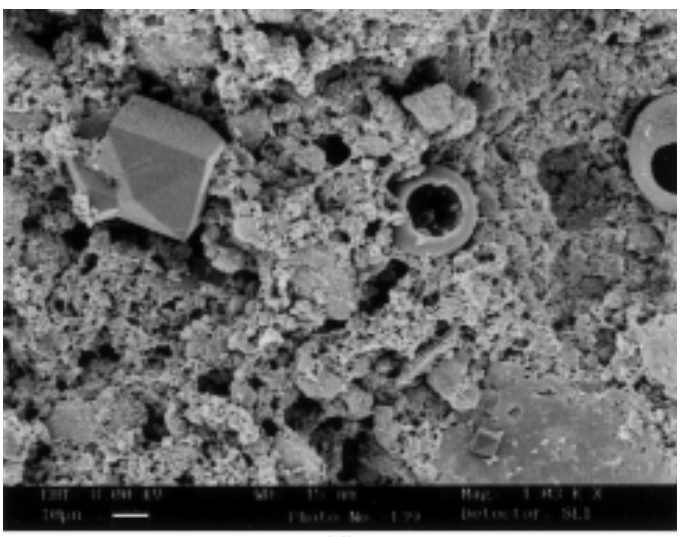

(d)

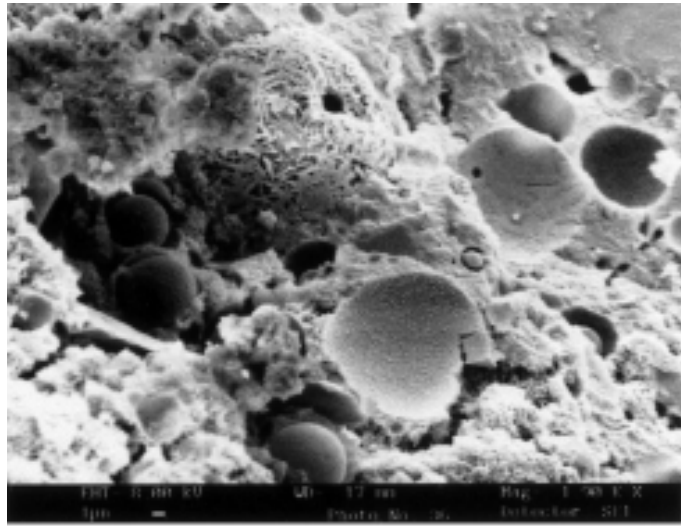

(f)

Fig. 10. Typical SEM micrographs at 5 years: (a) mix E, sand and gravel; (b) mix D, made ground; (c) mix B, made ground; (d) mix B, sand and gravel; (e) mix Bo, made ground; (f) mix Bo, sand and gravel

performance and a decreased permeability. Examining mixes $B$ and D, with the largest increase in UCS at 5 years, and mixes $A$ and $G$ with a decrease, the above correlations cannot be mapped onto the corresponding behaviour in durability and permeability. However, such a correlation should be investigated using more uniform materials and controlled test conditions.

(d) The remaining unused cores will be tested again in five years' time to investigate the behaviour at 10 years and hence provide a picture of the longer-term performance of this stabilised/solidified contaminated ground. (e) An ongoing follow-up EPSRC project is addressing many of the issues raised in this paper. The project is performing a fundamental study to investigate the significance and impact of the many factors and variables listed as possibly contributing to the observed performance over time. These can only be adequately investigated using model soils and contaminants and uniform mixing conditions, all performed under controlled laboratory conditions. Another related aspect being addressed is the development of experimental accelerated ageing techniques and test methods, which will allow the prediction of long-term 
behaviour. The accelerated ageing methods being employed are elevated temperatures and accelerated carbonation. These studies will be the subject of future publications.

\section{CONCLUSIONS}

In terms of the imposed design criteria, the physical and chemical properties tested show that the in situ stabilisation/ solidification treatment using soil mixing was generally still effective at 5 years, with continued hydration still taking place and with no serious sign of deterioration due to ageing. Although there is evidence of reduced strength and durability and increased permeability and leachability in some of the mixes, fluctuations in the behaviour should be expected owing to the complex nature and variability of the mixes. It was clear that mixing within the overlap columns was not very effective, and measures to improve this in practice have been suggested. It was generally difficult at 5 years to draw trends and comparisons between the various mixes. This implies that the effects of factors such as the effectiveness of mixing and the long-term interaction between the contaminants and the soilgrout constituents were dominant over those of the small differences in the grout constituents. The variability observed in the results is attributed to the presence of extraneous materials and to the variable level of mixing of the grout with the soil. It is therefore recommended, when testing soil-mixed stabilised/solidified contaminated ground, to test a larger number of samples than is usually specified in test methods. A follow-up EPSRC project involving fundamental studies using model soils and contaminants and accelerated ageing will shed some light on and isolate the effects of factors that influence the long-term performance of stabilised/solidified contaminated ground.

\section{ACKNOWLEDGEMENTS}

The Engineering and Physical Sciences Research Council is gratefully acknowledged for funding this work (Grant GR/N03297). May Gurney Technical Services are gratefully acknowledged for carrying out the re-excavation and coring of the treated ground. The authors also acknowledge the valuable discussions with Dr Chris Evans on various aspects of the project. In addition, the authors are grateful to the following, who helped with various aspects of the experimental work: Steve Chandler, Tim Ablett, Alan Heaver, Martin Touhey, Jim Francis and Andrew Moss.

\section{REFERENCES}

1. Evans D., JefFeris S. A., Thomas A. 0. and CuI S. Remedial Processes for Contaminated Land: Principles and Practices. Construction Industry Research and Information Association, London, 2001, CIRIA Report C549.

2. Al-TabbaA, A. and Evans C. W. Pilot in situ auger mixing treatment of a contaminated site. Part 3. Time-related performance. Proceedings of the Institution of Civil Engineers, Geotechnical Engineering, 2000, 143, No. 2, $103-114$.

3. Board M. J., Reid J. M., Fox D. S. J. and Grant D. I. The Effects of Age on Cement Stabilised/Solidified Contaminated Materials. Transport Research Laboratory, Crowthorne, UK, 2000, TRL Report 451.

4. BoARD M. J., ReID J. M., Fox D. S. J. and GRANT D. I. The long-term assessment of a cement stabilised/solidified contaminated made ground for use as a road construction material. Land Contamination and Reclamation, 2000, 8, No. 2, 75-85.

5. SANSOM M. R. and JARDINE F. M. CIRIA's case study demonstration programme: remedial technologies for treating contaminated land. Proceedings of First BGS Geoenviromental Engineering Conference (YONG R. N. and THomas H. R. (eds)). Thomas Telford, London, 1997, pp. 490-495.

6. Al-TabBaA A. and Evans C. W. Pilot in situ auger mixing treatment of a contaminated site: Part 1. Treatability study. Proceedings of the Institution of Civil Engineers, Geotechnical Engineering, 1998, 131, No. 1, 52-59.

7. Al-TabbaA A., Evans C. W. and Wallace C. J. Pilot in situ auger mixing treatment of a contaminated site. Part 2. Site trial. Proceedings of the Institution of Civil Engineers, Geotechnical Engineering, 1998, 131, No. 2, 89-95.

8. Allot and LomaX Contaminated Land and Building Investigation at Defence Research Agency, West Drayton, Phase II: Final Report, 1993.

9. INTERDEPARTMENTAL COMMITTEE FOR THE REDEVELOPMENT OF CONTAMINATED LAND. Guidance on the Assessment and Redevelopment of Contaminated Land, 2nd edn. Department of the Environment, London, 1987, ICRCL Paper 59/83.

10. Ministry of Housing, Spatial Planning ANd EnVIRONMENT. Intervention Values and Target Values: Soil Quality Standards. Department of Soil Protection, The Hague, The Netherlands, 1996.

11. Evans C. W. Studies Related to the in Situ Treatment of Contaminated Ground Using Soil Mix Technology. PhD thesis, Birmingham University, 1998.

12. ASTM. Compressive Strength of Moulded Soil-Cement Cylinders. American Society for Testing and Materials, Philadelphia, 1995, Vol. 04.08, Test D1633, pp. 254-256.

13. HEAD K. H. Triaxial consolidation and permeability tests. In Manual of Soil Laboratory Testing, Pentech Press, London, 1992, pp. $1001-1027$.

14. ASTM. Wetting and Drying Test of Solid Waste. American Society for Testing and Materials, Philadelphia, 1995, Vol. 11.04, D4843, pp. 152-155.

15. ASTM. Determining the Resistance of Solid Wastes to Freezing and Thawing. American Society for Testing and Materials, Philadelphia, 1995, Vol. 11.04, D4842, pp. $148-151$.

16. FEDERAL REgISTER. Toxicity characteristics leaching procedure. Federal Register, 51, No. 216, 40643-40652.

17. LeWin K., BradshaW K., Blakey N. C., Turrell J., Hennings S. M. and FLAVIN R. J. Leaching tests for assessment of contaminated land: Interim NRA guidance, NRA, R\&D Note 301, Bristol, UK, 1994.

18. US EnVIRonmental Protection Agency. Prohibition on the Disposal of Bulk Liquid Hazardous Waste in Landfills: Statutory Interpretive Guidance. USEPA, Washington, DC, 1986, Office of Solid Waste and Emergency Response Policy Directive No. 9487.00-2A, USEPA/530-SW-016.

19. Private Water Supplies Regulations. HMSO, London, 1991, Document No. 2790.

20. HARris M. R., Herbert S. M. and SMIth M. A. Remedial Treatment for Contaminated Land. Volume VII: Ex-Situ Remedial Methods for Soils, Sludges and Sediments. Construction Industry Research and Information Association, London, 1995, Special Publication 107, pp. $122-171$. 
21. BoES N. C. A. Long-Term Behaviour of Soil-Mixed in-Situ Treated Contaminated Ground. MPhil thesis, University of Cambridge, 2001.

22. ASTM. Obtaining and Testing Drilled and Sawed Beams of Concrete. American Society for Testing and Materials, Philadelphia, 1995, Test Method C42, Part 19, pp. 30-33.

23. SHERWOOd, P. T. Soil Stabilisation with Cement and Lime. HMSO, Norwich, 1993.

24. KIRK D. R. Summary of USEPA Research on Solidified/ Stabilized Waste for Long-Term Durability: Stabilisation and Solidification of Hazardous, Radioactive and Mixed
Waste. American Society for Testing and Materials, Philadelphia, 1996, ASTM STP 1240, Vol. 3, pp. 239-250.

25. LaGrega M. D., Buckingham P. L. and Evans J. C. Stabilization and Solidification: Hazardous Waste Management. McGraw-Hill, New York, 1994, pp. 641-704.

26. CONNER J. R. Chemical Fixation and Solidification of Hazardous Waste. Van Nostrand Reinhold, New York, 1993.

27. ENVIRONMENT Agency. Environmental Quality Standards. UK Environment Agency, Solihull, 2000.

Please email, fax or post your discussion contributions to the secretary by 18 December 2002: email: mary.henderson@ice.org.uk; fax: +44 (0)20 7799 1325; or post to Mary Henderson, Journals Department, Institution of Civil Engineers, I-7 Great George Street, London SWIP 3AA. 